\title{
Myometrial cytokines and their role in the onset of labour
}

\author{
S P Sivarajasingam ${ }^{1}, \mathbf{N}$ Imami² and M R Johnson'1 \\ 1Department of Surgery and Cancer, Imperial College London, Chelsea and Westminster Hospital, London, UK \\ 2Department of Medicine, Imperial College London, London, UK
}

Correspondence should be addressed to M R Johnson

Email

mark.johnson@imperial.ac.uk

\begin{abstract}
Human labour is an inflammatory event, physiologically driven by an interaction between hormonal and mechanical factors and pathologically associated with infection, bleeding and excessive uterine stretch. The initiation and communicators of inflammation is still not completely understood; however, a key role for cytokines has been implicated. We summarise the current understanding of the nature and role of cytokines, chemokines and hormones and their involvement in signalling within the myometrium particularly during labour.
\end{abstract}

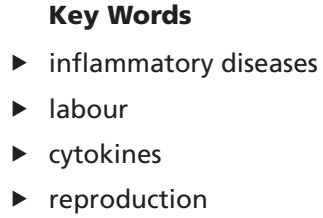

Journal of Endocrinology (2016) 231, R101-R119

\section{Introduction}

Human labour is an inflammatory event, physiologically driven by an interaction between hormonal and mechanical factors and pathologically associated with infection, bleeding and excessive uterine stretch (Golightly et al. 2011). However, the processes involved are not fully understood, especially the triggers/activators of labour. Local pro-inflammatory cytokine and chemokines have been implicated in the pathophysiology of human labour since the 1980s; with more recent data strongly linking increased intrauterine cytokine and chemokine production with both term (TL) and preterm labour (PTL) (Keelan et al. 2003).

Various inflammatory mediators have been studied in reproductive tissues obtained at the time of TL and PTL showing the involvement of a range of cytokines and chemokines in the choriodecidua (Hamilton et al. 2013), amnion (Gomez-Lopez et al. 2010) and placenta (Haugueldemouzon \& Guerremillo 2006). This review will be focused on recent work and current understanding of the nature and role of cytokines, chemokines, and hormones and their involvement in signalling within the myometrium particularly during labour.

\section{Myometrial inflammation}

Inflammation typically involves white cell infiltration and the production of cytokines that induce changes in cell function through the modulation of gene expression. It is a highly coordinated process designed to protect the organism from infection (Meeusen et al. 2001, Martinon et al. 2009), but can be induced by other stimuli including chemicals and damaged cells. Generally, the inflammatory response is beneficial to the host, but when it is directed against components of the body as in joints in rheumatoid arthritis for example, or when it is excessive, such as in septic shock, inflammation can be harmful. In the myometrium, with the onset of labour at term, inflammation is thought to play a physiological role transforming the myometrium from a quiescent to a contractile state. In contrast, in PTL, inflammation takes on a pathological role, precipitating early delivery in response to a variety of triggers including infection, overdistension and haemorrhage.

The first reports of myometrial inflammation in association with labour appeared in the later 1980s. Azziz and coworkers reported the presence of inflammation in biopsies taken at the time of emergency Caesarean section

Published by Bioscientifica Ltd 
and suggested that there was an underlying infective cause (Azziz et al. 1988). Lopez-Bernal and colleagues first raised the key question of how much of the inflammatory change in the myometrium was a consequence of the labour process (Bernal et al. 1993). This question was partially addressed in a series of papers by Norman and coworkers in which the nature of the cellular infiltration, the changes in cytokine levels and the cells producing the cytokines were defined (Bollopragada et al. 2009). These papers established that TL is an inflammatory event showing that the myometrium is infiltrated by neutrophils, macrophages and T lymphocytes (Fig. 1) and that these cells are the predominant source of the inflammatory cytokines (Young 2002). Later studies have shown that the myometrial expression of chemokines and endothelial adhesion molecules are increased with the onset of labour, suggesting a potential underlying mechanism for the cellular infiltration of the myometrium (Young 2002). The drivers of the chemokine expression have also been studied and may include mechanical stretch and cytokines (see below). However, it remains unclear whether the inflammatory infiltration of the myometrium is a cause or consequence of labour. Human studies show that levels of IL-8 (Table 1) rise with established labour only (Osmers 1995, Elliott et al. 2001, Kemp et al. 2002a,b). In rodent pregnancies, it seems apparent that the inflammatory infiltration precedes the onset of labour (Mackler 1999, Shynlova et al. 2012b), but various groups have depleted pregnant animals of neutrophils (Timmons 2006) or studied animals with no mast cells (Menzies et al. 2011), without delaying labour onset. Others have used chemokine knockouts, which deliver at the same time as their wild-type controls (Menzies et al. 2012). A number of animal studies have attempted to address this question using LPS, a bacterial wall polysaccharide (Fang et al. 2000). Lye and coworkers found that pre-treatment with a non-specific chemokine antagonist delayed labour onset in association with a reduced inflammatory infiltration (Shynlova et al. 2014), suggesting that the inflammatory infiltration is important in inflammation-induced labour onset. Indeed, macrophage depletion prevents LPSinduced PTL in pregnant mice (Gonzalez et al. 2011), but neutrophil depletion had no effect (Rinaldi et al. 2014). These data suggest that macrophages but not neutrophils are important for this process.

\section{Inflammation in reproductive tissues/compartments}

The inflammatory changes may be a consequence of inflammation in other areas.

\section{Maternal circulation}

The changes in the innate immune system during pregnancy are characterised by increased numbers of circulating monocytes and granulocytes, resulting in a higher number of total leukocytes (Tang et al. 2015). Peripheral monocyte numbers are higher, mainly due to

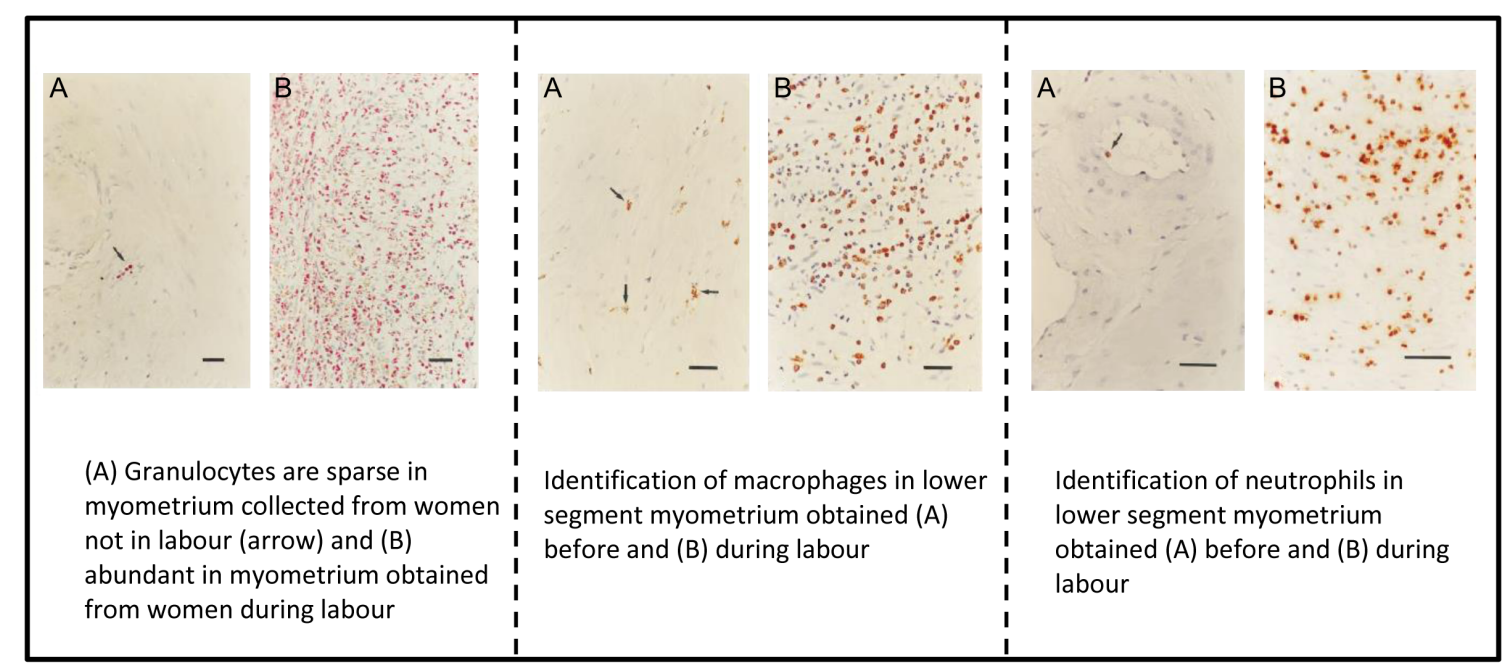

Figure 1

Leukocytes infiltrating the myometrium during parturition. Reproduced from Thomson AJ, Telfer JF, Young A, Campbell S, Stewart CJR, Cameron IT, Greer IA \& Norman JE, Leukocytes infiltrate the myometrium during human parturition: further evidence that labour is an inflammatory process, Human Reproduction, 1999, volume 14, issue 1, pages 229-236, by permission of Oxford University Press.

http://joe.endocrinology-journals.org DOI: 10.1530/JOE-16-0157
๑ 2016 Society for Endocrinology Printed in Great Britain
Published by Bioscientifica Ltd. 
Table 1 Summary of nature and role of key soluble mediators in myometrium.

\begin{tabular}{|c|c|c|}
\hline Cytokine/Chemokine & Role in myometrium & Evidences \\
\hline IL-1 $\beta$ & $\begin{array}{l}\text { - Pro-inflammatory IL-1 cytokine } \\
\text { superfamily } \\
\text { - Source - monocytes, macrophages mainly } \\
\text { - Stimulates arachidonic acid release, activate phospholipid } \\
\text { metabolism and increase the production of prostaglandins by } \\
\text { the myometrium } \\
\text { - IL-1 } \beta \text { activates a signal transduction system involving NF-KB to } \\
\text { increase the expression of COX-2, which is increased in the } \\
\text { myometrium during labour and stimulates the production of } \\
\text { PGE2 by myometrial cells }\end{array}$ & Peltier (2003), Krishnan et al. (2014) \\
\hline IL-6 & $\begin{array}{l}\text { - Pro-inflammatory cytokine and anti-inflammatory myokine } \\
\text { - Source - monocytes, macrophages, endothelial cells } \\
\text { - IL-6 has no effect on prostaglandin production by myometrial } \\
\text { cells and is unable to stimulate myometrial contractions } \\
\text { - This cytokine may play a role in labour by increasing the } \\
\text { expression of oxytocin receptors on myometrial cells to } \\
\text { increase their responsiveness to oxytocin } \\
\text { - IL-6 can also increase oxytocin secretion by myometrial cells }\end{array}$ & Peltier (2003) \\
\hline IL-8 & $\begin{array}{l}\text { - Chemotactic and pro-inflammatory cytokine } \\
\text { - Source - macrophages, endothelial cells } \\
\text { - IL-8 is chemotactic to neutrophils } \\
\text { - Increase in myometrium in term labour compared to preterm } \\
\text { labour; may work by increasing PGE } \\
\text { - Progesterone and dexamethasone have been shown in vitro to } \\
\text { inhibit IL-8 }\end{array}$ & $\begin{array}{l}\text { Baggiolini et al. (1995), Keelan et al. } \\
\text { (2003), Terzidou et al. (2006) }\end{array}$ \\
\hline TNF- $\alpha$ & $\begin{array}{l}\text { - Pro-inflammatory cytokine } \\
\text { - Source - macrophages, monocytes } \\
\text { metabolism and increase the production of prostaglandins by } \\
\text { the myometrium }\end{array}$ & Peltier (2003), Idriss \& Naismith (2000) \\
\hline $\mathrm{CCL} 2$ & $\begin{array}{l}\text { - Pro-inflammatory soluble chemoattractant cytokine } \\
\text { - Source - monocytes, lymphocytes, endothelial cells, fibroblasts } \\
\text { - Uterine smooth muscle cells can secrete CCL2, which can lead } \\
\text { to inflammation by promoting recruitment of monocytes to } \\
\text { myometrium } \\
\text { - Mechanical stretch of the myometrium increases expression } \\
\text { of CCL2 }\end{array}$ & Shynlova et al. (2008) \\
\hline
\end{tabular}

an increase in the intermediate monocyte subset (Melgert et al. 2012). These monocytes are pro-inflammatory, producing IL-1 $\beta$, IL-6 and TNF- $\alpha$ (Tang et al. 2015) (Table 1) and are recruited into gestational tissues, especially the decidua, during labour (Tang et al. 2015). Peripheral circulating leukocytes have also been noted to display early chemotactic responsiveness during late gestation, which would aid their infiltration into uterine tissues (Gomez-Lopez et al. 2013). Recently, Srikhajon and coworkers reported that monocytes are recruited first to the myometrium by various cytokines and chemokines. Following this transmigration, activated monocytes in turn limit further chemotaxis by disrupting locally established CCL2 gradients (Table 1) (Srikhajon et al. 2014). This may serve as a negative feedback loop to control the local inflammation. On the other hand, this group also suggested that generic inhibition of chemokines limited inflammation and reduced PTB (Shynlova et al. 2014). These seeming contradictions may reflect species differences or be determined by the stimulant. Circulating neutrophil numbers are higher in women in PTL and TL (Yuan et al. 2009). These neutrophils are likely to be drawn into the myometrium by chemokines in particular IL-8 which is significantly higher in myometrium at term during labour than in women not in labour (Gomez-Lopez et al. 2010) and may contribute to the changes in whole blood gene expression noted in women with threatened PTL (Heng et al. 2014).

Amniotic fluid Inflammatory cytokines are known to increase in AF towards term in human pregnancy and may play a role in labour by stimulating local production

Published by Bioscientifica Ltd 
of prostaglandins (PGs) and collagenases (Bowen et al. 2002). With the onset of TL, there are increased concentrations of IL-1 $\beta$ and TNF- $\alpha$ in AF (Romero et al. 1990, Laham et al. 1993). IL-6 has been noted to be raised in AF in women with spontaneous labour (Andrews et al. 1995) and particularly raised in PTL associated with intraamniotic infection; and even considered a predictor for PTL before 34 weeks gestation (Chaemsaithong et al. 2015). IL-8 concentrations in AF increase progressively from early pregnancy to term and more markedly with the onset of spontaneous TL (Romero et al. 1991, Saito et al. 1993, Laham et al. 1994). The rise in AF IL-6 precedes that of IL-8, suggesting that IL-6 has a role in the initiation of the inflammatory cascade required for the onset of labour (Kemp et al. 2002a,b). Recent work by Romero and coworkers have shown varying cytokine networks noted in the AF associated with PTL with intact membranes and intra-amniotic inflammation (both microbial and sterile) (Romero et al. 2015). Interestingly, the chemokine CCL-20, which targets immature dendritic cells, effector/ memory $\mathrm{T}$ cells and $\mathrm{B}$ lymphocytes increases in AF with advancing gestational age. It is further increased in the absence of infection in spontaneous TL and PTL, which suggests it has a role in the common parturition pathway (Hamill et al. 2008).

Amnion/Chorion Inflammation has been seen in amnion and chorion with IL-1 $\beta$ and IL-8 increasing in concentration in the third trimester (Keelan et al. 1999, Elliott et al. 2001). This is a key observation as it implies that the inflammatory process begins before the onset of labour. The expression of both cytokines was increased after labour with chorion producing more of each cytokine than the amnion (Elliott et al. 2001). In addition foetal membranes have exhibited selective chemotaxic activity in human labour, consequently increasing monocytes, T cells and NK cells (Gomez-Lopez et al. 2009). IL-6 and TNF- $\alpha$ are also increased (Young 2002), contributing to the chemotaxis of monocytes and other immune cells into the gestational tissues, including into the myometrium and cervical stroma (Elliott et al. 2001, Golightly et al. 2011).

Choriodecidua (CD) The decidua is a highly immunologically active region of a pregnant uterus. Hamilton and coworkers used a rat model to investigate the pre-labour changes and found a significant increase in the numbers of macrophage infiltration of the decidua in the days before labour, which preceded inflammatory changes in the myometrium (Hamilton et al. 2011). This suggests that decidual inflammatory events are important in the initiation of labour (Sindram-Trujillo et al. 2004, Castillo-Castrejon et al. 2013), supporting the hypothesis first proposed in the 1980s that decidual activation is an early event in the labour cascade (Casey \& MacDonald 1988). IL-8 is raised in CD at labour, with almost a 30-fold change in TL compared with term no labour (Hamilton et al. 2013), resulting in neutrophil recruitment. These cells can release several inflammatory mediators and MMPs, which could degrade the extracellular matrix of the foetal membranes during both TL and PTL, contributing to ROM during TL and PTL (Gomez-Lopez et al. 2010). CD changes are of particular interest in PTL, where it has been shown that CD56+ NK cells and T cells are increased (Hamilton et al. 2013) along with an elevated expression of CCL8, which is a chemoattractant for NK and T cells (Proost et al. 1996). These inflammatory changes implicate both the innate and adaptive immune system in the pathological process of PTL and interestingly the imbalance among these two immune systems in PTL have been demonstrated via a mouse model (Arenas-Hernandez et al. 2016).

Placenta In contrast to the foetal membranes and decidua, the evidence of placental inflammation is poor (Keelan et al. 1999). The placenta is a site of peripheral monocytic activation, where monocytes encounter the villous trophoblast (Tang et al. 2015). Studies of placental cells and tissue in vitro have demonstrated their ability to respond to inflammatory stimuli such as pathogenic bacteria, LPS or IL-1 with increased production of cytokines (IL-1, IL-6, IL-10), chemokines (macrophage chemotactic protein-1 (MCP-1), IL-8) and prostanoids (Denison et al. 1998, Goodwin et al. 1998, Gniesinger et al. 2001). This highlights the capacity of the placenta to play a key role in the inflammatory process associated with PTL triggered by abruption or infection.

Overall, inflammation does play a critical role in the onset and progression of labour, but where this is initiated and then propagated to is still a point of much discussion and research. It seems likely that the decidua being the maternal foetal interface is immunologically crucial, and our data (unpublished) suggests that it is the most inflammatory in PTL. Further work looking at inflammation in all compartments with comparison to peripheral blood is necessary to improve our understanding. The exact triggers for the onset of this inflammatory process is yet another uncertainty; some

Published by Bioscientifica Ltd. 
have suggested that the foetus releases surfactant proteins as a signal of maturity (Reinl \& England 2015), others that there is a change in maternal tolerance and still others that uterine stretch is responsible.

\section{Physiology}

Stretch effect Throughout pregnancy, the uterus is dramatically remodelled to accommodate the growing pregnancy. Despite the progressive increase in size, uterine quiescence is maintained, until the onset of labour, be it at term or preterm; then when the uterus transforms into an actively contractile organ, to efficiently expel the pregnancy. The growing conceptus increases intra-uterine pressure, but for the majority of pregnancy, the uterus is able to adapt and remodel to avoid any increase in wall tension. It is possible that once this adaptive mechanism is lost or overcome, the tension in the wall of the uterus rises, initiating the process, which culminates in the onset of labour. Progesterone has been suggested to play a key role in this adaptive process, particularly in animal models, where the loss of progesterone repression is associated with an increase in stretch-related procontraction proteins (Shynlova et al. 2012a) (connexin-43 and oxytocin receptor (OTR)). In vitro stretch models of human myometrial cells (Terzidou et al. 2005) and strips (Moraitis et al. 2015) showed increased OTR expression and responsiveness, respectively, while in vivo, acute uterine stretch increases PG synthesis (Manbe et al. 1982). Interestingly, no difference in prolabour gene expression was seen when comparing twin and singleton pregnancies (Lyall 2002). Equally, excessive uterine stretch, seen in polyhydramnios, multiple pregnancy or a singleton pregnancy in a unicornuate uterus are all associated with increased rates of PTL (Rodriguez 1992, Reichman et al. 2009, Conde-Agudelo \& Romero 2014) (Fig. 2).

In vivo animal models of stretch in pregnancy has been pioneered by Lye and coworkers who uses a unilateral pregnant rat model and compares the effect of mechanical strain imposed by the growing foetus in the gravid horn to the changes observed in empty horn. Lye and coworkers showed that CCL-2 levels increased in the gravid uterine horn and reproduced this effect by in vitro stretch of myometrial cells (Shynlova et al. 2008). More recently, Adams-Waldorf, using a non-human primate model, demonstrated the effect of stretch on the inflammatory response of the uterus by recreating uterine distension through balloon inflation. There was significant elevation of pro-inflammatory cytokines, including IL-1 $\beta$, IL-6, IL-8, CCL-2 and TNF- $\alpha$, which was

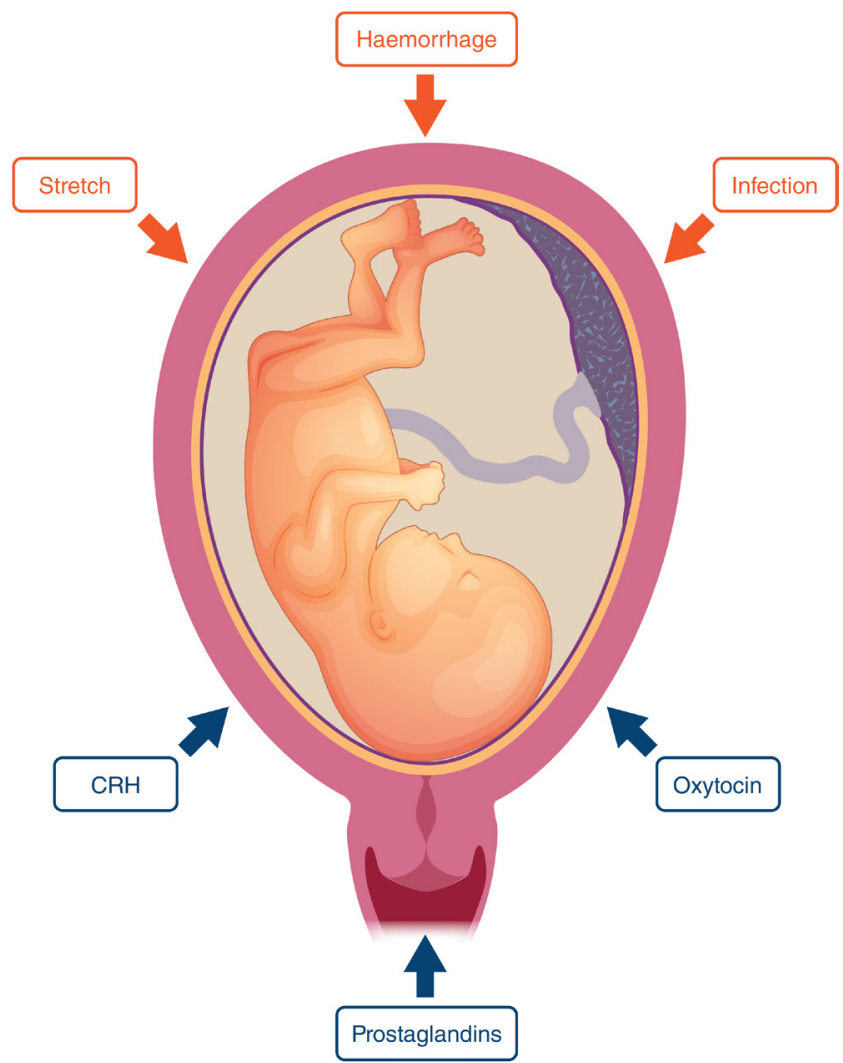

Figure 2

Pathology and hormones that promote myometrial contractility. Adapted, with permission, from Romero R, Dey SK \& Fisher SJ, 2014, Preterm labor: one syndrome, many causes, Science, volume 345, pages 760-765. Reprinted with permission from AAAS.

compared with the inflammatory response observed in human twin PTL (Adams Waldorf et al. 2015).

Some studies have stretched human myometrial strips and shown an increase in IL-8 levels (El Maradny et al. 1996). More recent studies revealed that prolonged stretch of human myometrial strips under high tension resulted in increased myometrial contractility (Tattersall et al. 2012). The pathway by which the myometrial contractility is enhanced has not been defined; however, there is evidence the stretch stimulates the expression of a known smooth muscle stimulatory agonist, gastrinreleasing peptide (Tattersall et al. 2012). Another theory that has been postulated is that stretch of myometrium under high tension induces constitutive activation of the OTR (Moraitis et al. 2015). This was supported by the observation that retosiban, an OTR blocker, reduced the pro-contractile effects of stretch (Moraitis et al. 2015).

In vitro studies of human and rat myometrial cells show that mechanical stretch upregulates pro-inflammatory factors (Shynlova et al. 2012b). Our studies showed that

Published by Bioscientifica Ltd 
stretch upregulated IL-8 and COX-2 in a MAPK-dependent manner (Loudon 2004, Sooranna 2004, Sooranna et al. 2005). Later studies confirmed that stretch of myometrial cells increased the expression and release of IL-8, while showing that other chemokines and inflammatory cytokines are also increased in a predominantly NFkBdependent manner (Hua et al. 2012). More recently, Lye and coworkers showed that conditioned media from stretched myometrial cells induced endothelial activation and the expression of adhesion molecules, promoting the extravasation of inflammatory cells (Lee et al. 2014).

Lee and coworkers tested the hypothesis that the stretch enhances peripheral leukocyte extravasation into the term myometrium through the release of various soluble mediators, including cytokines and chemokines, by human uterine myocytes. Nine cytokines/chemokines were significantly increased by stretch: IL-6, IL-12p70, IL-8, CXCL1, MIF (macrophage migration inhibitory factor), G-CSF, bFGF (basic fibroblast growth factor), VEGF, and PDGF-bb (platelet-derived growth factor subunit B). The greatest effect of stretch was seen on CXCL1 and IL-8 (Lee et al. 2014). In human myometrial cells, the stretch-induced increase in CXCL1 and IL-8 was greatest at $6 \mathrm{~h}$ (Hua et al. 2012). CXCL1 and IL-8 have been widely reported to be associated with TL, when both are likely to interact with neutrophils expressing CXCR1 and CXCR2, promoting myometrial infiltration of neutrophils in the gestational tissues (Elliott et al. 2000, Bollopragada et al. 2009).

Chemokines are essential for inflammatory cell migration and also modulate immune cell activation (Griffith et al. 2014). The main chemokines implicated in the inflammatory process of labour are IL-8 and CCL2, which act via CXCR2 and CCR-2, respectively. IL-8 is a potent chemokine for neutrophils; and its mRNA expression is increased in myometrium of women in PTL and TL (Keelan et al. 2003). Indeed, a recent myometrial transcriptome study reported that IL-6, CXCL1 and IL-8 exhibited the greatest increase in labouring samples (Mittal et al. 2010). A more detailed study revealed that IL-8 levels increased in parallel with cervical dilation (Hebisch et al. 2001). In PTL, IL-8 concentrations are markedly elevated in chorioamnionitis (CA) (Yoneda et al. 2015). Interestingly, myometrial expression of CXCR2 declined with the onset of TL (Hua et al. 2012), perhaps as a result of higher IL-8 levels or the effects of increased levels of OT and $\mathrm{PGF}_{2 \mathrm{a}}$, which can also repress CXCR2 expression via phospholipase C (Hua et al. 2012). Alternatively, IL- $1 \beta$ and TNF- $\alpha$ also reduce CXCR2 expression and may also be responsible for the labour-associated decline (Hua et al. 2012).
CCL-2 is a member of the CC chemokine family and is also called MCP-1 (Esplin et al. 2005, Griffith et al. 2014). It is expressed by decidual cells (Critchley et al. 1996), endometrial and myometrial cells (Arici et al. 1995, Jones et al. 1997) therefore it is ideally positioned to recruit macrophages to cervix, myometrium and foetal membranes with the onset of labour. Indeed, CCL-2 is markedly upregulated in both term and preterm myometrium (Esplin et al. 2005). CCL-2 is increased in amniotic fluid (AF) from women in PTL, particularly in the presence of infection (confirmed by histological CA) (Esplin et al. 2003).

Stretch clearly has an impact on not only proinflammatory mediators such as CCL-2, IL-8 and IL-6, but also on activity of OTRs and smooth muscle agonists such as gastrin-releasing peptides. Much of the in vivo model findings have been confirmed in our in vitro work; however, further work looking into the interactions among electro-mechanical signalling, hormonal interference and inflammation is necessary to understand when adaptive mechanisms that maintain uterine quiescence falter.

Maternal tolerance Pregnancy has often been compared with a transplanted organ as both foetus and placenta express maternal and paternal antigens hence are like semi-allografts (Erlebacher 2012). Breakdown in immune tolerance has been linked to rejection, which in pregnancy can have variable consequences depending on the gestation: recurrent miscarriages (Kuon et al. 2015), PTL (Romero et al. 2014a) and pre-eclampsia (Dietl 2000). Tolerance is maintained via factors produced at the implantation site, one such promoter of tolerance is IL-10, an anti-inflammatory cytokine (Thaxton \& Sharma 2010). IL-10 was demonstrated to be a modulator of uterine NK cell cytotoxicity; in an IL-10 depleted mice model, very low doses of LPS led to uterine NK (uNK) cell activation and foetal demise (Murphy et al. 2008). In a non-human primate model, IL-10 has been shown to inhibit IL-1 $\beta$ induced uterine activity (Sadowsky et al. 2003) and it seems to also have an inhibitory effect on LPS induction of matrix metalloproteinase 2 and 9 in foetal membranes (Fortunato et al. 2001).

Interferons, known for their anti-viral potential, also have an immunomodulatory role (Racicot et al. 2014). Hertelendey and coworkers showed via human myometrial cell line cultures that cell cultures primed with IFN- $\gamma$ produced significantly less PGs and reduced COX-2 expression (Hertelendy \& Zakár 2004). It has been suggested that trophoblasts enable appropriate tolerance by 'educating' macrophages and adapting the cytokine

Published by Bioscientifica Ltd. 
profile of the local macrophages. Fest and coworkers showed that monocytes cultured with trophoblasts (Fest et al. 2007) increased production of RANTES (which recruits T-regulatory cells) and MIP- $1 \beta$, which both have immunosuppressive functions (Wang et al. 1999, Ramhorst et al. 2004). Dendritic cells (DC) promote cell tolerance particularly at the maternal-foetal interface, by priming T-regulatory $\left(\mathrm{T}_{\text {reg }}\right.$ ) cells (Blois et al. 2007). $\mathrm{T}_{\text {reg }}$ cells, part of the adaptive immune system play a pivotal role in promoting foetal survival by avoiding the recognition of semi-allogenic tissues by the maternal immune system (Somerset et al. 2004, Tilburgs et al. 2009, La Rocca et al. 2014). This was seen in a mice model where depletion of $\mathrm{CD}^{2} 5^{+} \mathrm{T}_{\text {reg }}$ cells led to gestation failure (Aluvihare et al. 2004) and a certain systemic composition of $T_{\text {reg }}$ cells with distinct subsets have been associated with PTL (Steinborn et al. 2011).

Maternal tolerance is no doubt vital to support a pregnancy to term, and to avoid pregnancy complications such as foetal loss and pre-eclampsia. PTL without an obvious cause, commonly referred to as idiopathic PTL is presumed by many as an immunological phenomenon with various immune cells considered culprits including high uNK cells or low $\mathrm{T}_{\text {reg }}$ cells. Many of these conclusions have arisen from in vivo models, which although highly informative, cannot take into consideration the movement, interaction and adaptability of immune cells between gestational tissue layers, between the periphery and the uterus and the mother and foetus.

Feto-placental signalling Corticotropin-releasing hormone $(\mathrm{CRH})$ is synthesised in the placenta and the levels of placental CRH increases as the pregnancy advances, peaking at delivery with a rapid decline postnatally (Sasaki et al. 1987). CRH can induce the breakdown of mast cells, releasing histamine (Lytinas et al. 2003) and has been widely associated with cytokines especially the pro-inflammatory cytokine IL-6 (Venihaki et al. 2001). Raised maternal levels of CRH have been associated with PTL (Fig. 3), suggesting a possible causative link (Vitoratos et al. 2007). Indeed, CRH can stimulate the myometrium to produce pro-inflammatory cytokines and chemokines, in particular IL-6, IL-1 $\beta$, TNF- $\alpha$, IL-8 and CCL2. However, this effect appears to be dependent on cAMP-PKA signalling pathway and possibly NF-кB (You et al. 2014). These cytokines can induce the chemotaxis of monocytes to the myometrium and promote inflammation, which is thought to be key for the onset of labour. For example, IL- $1 \beta$ and IL- 6 stimulate uterine activation by increasing CX43, PGFR and OTR. In addition, CRH has been reported to have a stimulatory effect on PGs (PGE2, PGF2 ${ }_{\alpha}$ ) (You et al. 2014).

IL-6 is a pro-inflammatory cytokine that is also recognised as a myokine. IL-6 and CRH are secreted in a pulsatile manner during active labour, with the increases in IL-6 preceding those of CRH (Papatheodorou et al. 2013). This suggests the hypothesis that IL-6 promotes the release of placental CRH and in a direct or indirect manner is associated with uterine contractility (Papatheodorou et al. 2013). IL-6 has been identified in cervico-vaginal fluid as a predictive marker of PTL in the subsequent 7 days (Jung et al. 2015). Some studies have suggested this to be secondary to sub-clinical CA as a majority of PTL is associated with infection (Jung et al. 2015). IL-6 concentrations, along with other cytokines, do not correlate with cervical shortening (Chandiramani et al. 2012).

Aside from CRH, surfactant protein-A (SP-A) from the foetal lung can induce parturition. Surfactant is a glycerophospholipid-rich lipoprotein, produced by alveolar type II pneumocytes and is secreted into AF with foetal breathing movements (Mendelson 2009). In murine models, injection of SP-A into the amnion resulted in preterm delivery (Reinl \& England 2015), interestingly this was done by shuttling $\mathrm{AF}$ macrophages to the myometrium and increasing uterine IL- $1 \beta$ levels (Condon et al. 2004). SP-A-deficient mice demonstrated a delay in parturition associated with suppressed myometrial inflammation and increased maternal progesterone (Reinl \& England 2015). In human models, SP-A stimulated PG synthesis (Bernal et al. 1988) and Johnston and colleagues have proposed that platelet-activating factor, a phospholipid component of foetal lung surfactant that is secreted into AF near term, may play an important role in the activation of myometrial contractility (Toyoshima et al. 1995).

CRH and SP-A are known proteins that can increase the production of cytokines and PGs, consequently triggering myometrial activity. In addition, there are likely to be other molecules released from not only the foetus and the placenta, but also from the membranes that increase myometrial inflammation. Further work to identify such molecules and its role and interactions is required.

Progesterone and progesterone receptor The withdrawal of progesterone (P4) has long been

Published by Bioscientifica Ltd. 


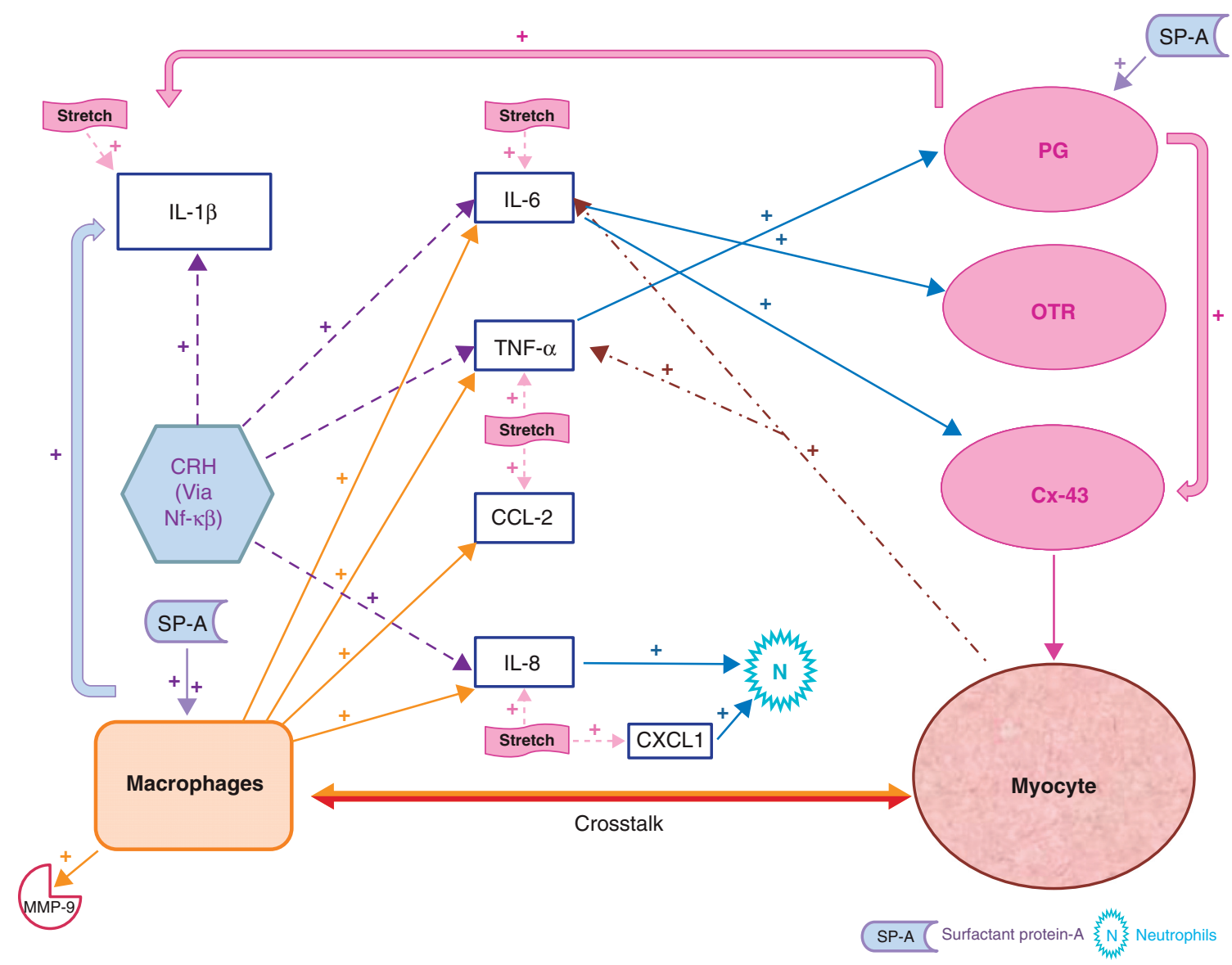

Figure 3

The effect of physiology (including stretch, surfactant protein-A and corticotropin-releasing hormone) on cytokines and myometrial contractility.

hypothesised to be the trigger of labour, with supportive evidence from animal models, in particular sheep and goat where a fall in P4 and a concurrent increase in oestradiol precedes the onset of labour (Ravanos et al. 2015). This does not apply to humans, as there is no decline in circulating maternal P4 levels before labour. Interestingly, guinea pigs are similar to humans in that they labour in the presence of high maternal progesterone levels. Such model has recently shown that decreasing P4 receptors leads to a physiological mechanism of functional P4 withdrawal, which is enhanced by endogenous/exogenous PG administration (Welsh et al. 2014).

$\mathrm{P} 4$ maintains uterine quiescence through suppression of contraction-associated proteins such as connexin 43 (Challis et al. 2000). It also exerts an anti-inflammatory action via inhibition of cytokine production and immune cell migration into the uterus and suppresses the transcription of genes that promote contractility. Interestingly, in human labour, a functional impairment in P4 receptor levels have been reported near term, which may reverse P4's suppressive actions, therefore, promoting myometrium's sensitivity to contract (Ravanos et al. 2015).

P4 has been suggested to maintain pregnancy primarily by inhibiting inflammation through repression of the archetypical inflammatory transcription factor NFkB (Wissink 1996). This is mediated both via a direct interaction between the $\mathrm{P} 4$ receptor, PR-B, and the principle NFkB subunit, p65, and by increasing IкB levels, which binds to p65 maintaining it in an inactive state (Hardy et al. 2006). The onset of human labour is suggested to occur after P4 influence is lost by a combination of increased expression of PR-A (Mesiano et al. 2002), which inhibits PR-B, a reduction in the level of the PR co-activator, SRC1 (Condon et al. 2006) and by increased activity of $\mathrm{NFKB}$, which represses PR activity via a direct interaction (Condon et al. 2003). Much of these data are based on over-expression of PR and p65, and have often 
been carried out in cell lines of various types. Our data suggest that P4 represses IL-1 $\beta$-driven COX-2 expression via the glucocorticoid receptor and not $\mathrm{PR}$, despite the presence of sufficient PR to modulate the expression of the P4-responsive genes (Lei et al. 2012). Further, we show that $\mathrm{P} 4$ reduced IL-1 $\beta$-driven COX-2 expression via the inhibition of AP-1 action rather than NFkB (Lei et al. 2015). Most work has focused on the effect of IL-1 $\beta$-driven activation of NFkB on PR function, but other cytokines may also modulate PR function. Confirmation of these potential interactions awaits further study.

\section{Pathology}

Infection Infection is the leading known cause of PTL and unfortunately one in three preterm infants are born to mothers with an intra-amniotic infection that is largely subclinical (Romero et al. 2001). Ascending infection is seen as the main source; however, there is an association between periodontal disease and PTL (Manegold-Brauer et al. 2014), which suggests a possible systemic dissemination and transplacental passage (Fig. 4).

Ascending infection is usually caused by common vaginal pathogens such as Group B Streptococcus, Mycoplasma and Ureaplasma, whereas periodontal disease is commonly caused by gram-negative anaerobic bacteria such as Aggregatibacter actinomycetemcomitans, Fusobacterium nucleate and Campylobacter rectus. These microorganisms and their products are typically identified by pattern recognition receptors such as toll-like receptors, which induce the production of chemokines (IL-8, IL-1, CCL-2) and cytokines (IL-1 $\beta$, TNF- $\alpha$ ) (Romero et al. 2014a). With regard to periodontitis pathogens it is likely that their effect is triggered by translocation of bacterial products, such as LPS, which can trigger common parturition pathway via inflammatory mediators such as IL-6 and TNF- $\alpha$ (Parthiban 2015).

PTL like TL require PGs. The rate-limiting enzyme in PG synthesis, PGHS-2, is required to increase PG just

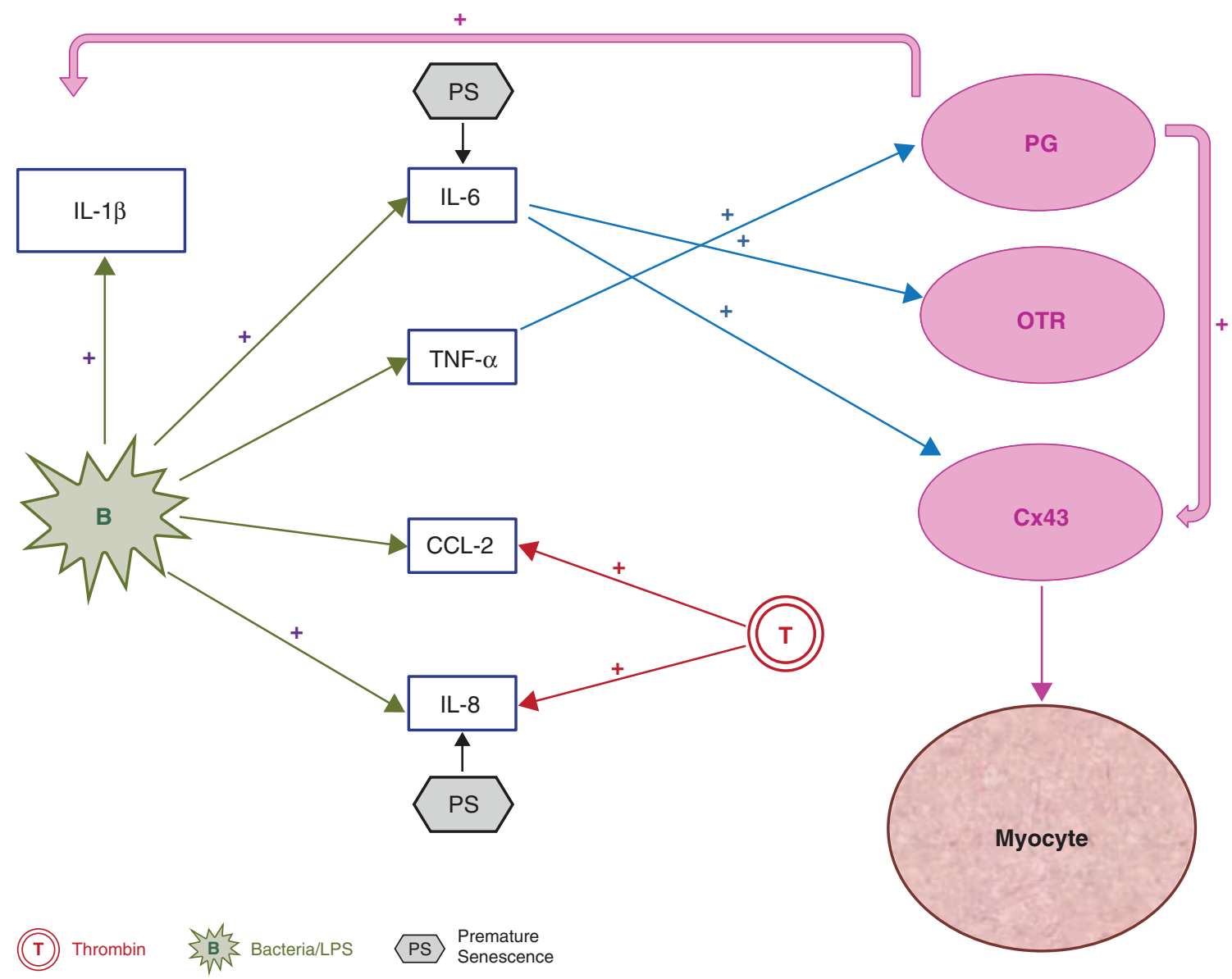

Figure 4

The effect of pathology (including haemorrhage, infection and premature senescence) on cytokines and myometrial contractility.

http://joe.endocrinology-journals.org DOI: 10.1530/JOE-16-0157
C 2016 Society for Endocrinology Printed in Great Britain
Published by Bioscientifica Ltd. 
before parturition (Hirst et al. 1995) and, interestingly, this is stimulated by cytokines including IL- $1 \beta$ and TNF- $\alpha$. The key role played by these specific cytokines is shown in mice lacking receptors for both IL- $1 \beta$ and TNF- $\alpha$, which have significantly lower levels of PGHS-2 mRNA in the myometrium following E. coli administration (Hirsch et al. 2006).

Aside from the above-mentioned infections, bacterial vaginosis (BV) and STIs are recognised as a risk factor for PTL, although treatment of asymptomatic women with $\mathrm{BV}$ does not reduce the rate of preterm births (Romero et al. 2001). One possible explanation for this association may be that $\mathrm{BV}$ induces the release of cytokines that trigger the onset of labour. Masson and coworkers identified that IL-1 $\beta$ (in cervico-vaginal fluid) as one of most useful immunologic biomarkers that could be used to diagnose treatable discharge-causing STIs and BV (Masson et al. 2016).

CA is a robust inflammatory response to intraamniotic infection, and commonly associated with an infiltration of neutrophils in response to IL-8 and CXCL6, amongst other chemokines (Kim et al. 2015b). Damageassociated molecular pattern molecules (see below) are also able to induce such neutrophil-attracting chemokine, which led to the possibility of a mutual parturition pathway. Recent work on immune cells involved in acute and chronic CA resulting in PTL has shown the importance of macrophages. It has highlighted differences in the anatomical distribution of macrophages within the foetal membranes, as well as the differing functions both pro-inflammatory and immunomodulatory (Bae et al. 2016). The plasticity and flexibility of macrophages (Brown et al. 2014), enables macrophages to acquire altered phenotypes in response to different situations. This is further complicated by the uncertainty of where these macrophages originate (foetal vs maternal) and the continuing conundrum of understanding the role of inflammatory signals in both TL and PTL. Indeed, variations in the onset of PTL and TL suggest that they may involve distinct inflammatory pathways, but as yet there are no definitive data on this subject.

It is important to note that sterile inflammation (defined as an inflammatory process without the presence of microorganisms) has also been associated to PTL and is more common in PTL with intact membranes than microbial-associated inflammation (Romero et al. 2014b). The aetiology of sterile intra-amniotic inflammation is unknown; however, the inflammation is understood to result from activation of the innate immune system by endogenous danger signals, derived from necrosis or cellular stress, termed damage-associated molecular pattern molecules, or alarmins (Gomez-Lopez et al. 2016). One such alarmin is HMGB1, which has been shown to induce PTL in a mouse model (Gomez-Lopez et al. 2016). For further detail on proposed theories on sterile inflammation please refer to Faranak Behnia's review (Behnia et al. 2016).

Haemorrhage Decidual haemorrhage is associated with PTL (Romero et al. 2014a) and it complicates $0.5-2 \%$ of all pregnancies (Buhimschi et al. 2010). Decidual haemorrhage was generally accepted as an acute event; however, histological evaluation of the vasculopathy accompanying decidual haemorrhage provides compelling evidence that the damage is frequently chronic (Salafia et al. 1995, Elsasser et al. 2010). Placental abruption has been shown to be associated with inflammatory lesions of the placenta, in particular at preterm gestations (Nath et al. 2007) and interestingly a strong association has been noted between severe CA and abruption at term (Nath et al. 2007). This suggests that inflammatory pathways are common to both infection and decidual haemorrhage.

Local decidual injury leads to production of cytokines, some of which lead to drive the inflammatory labour pathway. Additionally, thrombin, which is generated from decidual-cell-expressed tissue factor (Buhimschi et al. 2010), can itself enhance the activity of cytokines such as IL-8 (Lockwood et al. 2005) and CCL-2 (Matta et al. 2007), which enhance neutrophil and macrophage infiltration, promoting inflammation. Thrombin, acting via decidual cell membrane-bound protease-activated receptors, can also induce MMPs, which enable extracellular matrix breakdown, leading to the rupture of membranes (Han et al. 2011). This process has been associated with preterm premature rupture of membranes (PPROM) in the absence of infection (Han et al. 2011) and probably explains the linkage of PPROM and placental abruption in the absence of infection (Harger et al. 1990).

Thrombin has also been shown to be a direct potent uterotonic agent in both in vitro and in vivo models (Elovitz et al. 2000). In vitro fresh whole blood stimulated myometrial contractions in a dosedependent manner and this effect was supressed with thrombin inhibitors (Elovitz et al. 2000). In vivo thrombin increased the frequency, intensity and tone of myometrial contractions in a dose-related fashion (Elovitz et al. 2000). Thrombin's potential to be an

Published by Bioscientifica Ltd 
enzymatic, immunological and contractile inducer defines how decidual haemorrhage can expedite labour at term and unfortunately cause PTL when occurring at an early gestation.

Premature senescence Senescence refers to the physiologic and biomolecular mechanisms that are normal and naturally associated with ageing of a living organism (Muñoz-Espín \& Serrano 2014); however, premature senescence is associated with pathology such as diabetes (Barzilai et al. 2012) and chronic inflammatory conditions (Gubbels Bupp 2015). Senescence is also associated with a set of biomarkers that are referred to as senescenceassociated secretory phenotype (SASP). SASP is recognised by production of natural compounds such as cytokines, chemokines, matrix degrading enzymes and many more (Behnia et al. 2015). Behnia and coworkers showed that TL is associated with senescence of chorioamniotic membrane cells and increased pro-inflammatory SASP factors (IL-6, IL-8, GM-CSF) could function as triggers of labour (Behnia et al. 2015). Evidence of decidual senescence has been demonstrated in the basal plate of the placenta in cases with PTL, but not in women who delivered at term (Cha et al. 2013). Some regard senescence as an initiator of sterile inflammation, while Menon and colleagues suggest that inflammation at term, and maybe even preterm is secondary to foetal cell senescence (Behnia et al. 2015).

Pathological triggers of labour include infection (systemic and localised, i.e. CA), haemorrhage, and physiological deficits such as premature senescence. They all trigger pro-inflammatory markers and in general results in labour. However, it is unclear why some infections potentiate PTL and others only cause ruptured membranes and allow the pregnancy to continue to term. These variations may be due to the inflammatory marker response being stimulant (type of bacteria/antigenicity) and exposure (localised vs systemic) specific and may suggest triggering distinct inflammatory pathways.

Myometrial contractility The myometrium has the ability to contract both in a non-pregnant uterus in varying phases of the menstrual cycle and also importantly, in a pregnant uterus (Pehlivanoglu et al. 2013). This is evidently necessary as the process of parturition can only be completed with the establishment of regular and effective contractions. The switch from uterine quiescence to the active stage of contractility is considered to be dependent on a group of proteins referred to as contraction associated proteins (CAP) (Hutchings et al. 2009) whilst the excitation-contraction coupling required for contractility is understood to occur via elevated intracellular calcium levels (Wray 2003). For more detail please see Roger Smith's review (Smith 2007).

The direct effects of inflammation on contractility The upregulation of pro-inflammatory cytokines within labouring myometrium stimulates and potentiates uterine contractions (Voltolini et al. 2015). IL-1 $\beta$ enhance myometrial contractility via different pathways, promoting basal and store-operated calcium entry (Tribe 2002), upregulating TrpC expression (calcium entry channels; Dalrymple et al. 2004) and increasing the expression of selected phosphodiesterases, enzymes involved in the control of intracellular levels of cyclic nucleotides (Oger et al. 2002). TNF- $\alpha$ reduces the expression of Galphas, the component of the G-protein receptor complex that links to adenylyl cyclase and which increases intracellular cAMP levels promoting myometrial relaxation (Chapman et al. 2005). Interestingly, LPS increased the contraction of an isolated mouse uterine horn preparation (Mackler 2003) and uterine myocytes in vitro through the Rho/ROCK signalling pathways (Hutchinson et al. 2013) and co-culture of uterine myocytes and monocytes enhances cytokine production and contraction (Rajagopal et al. 2015). Myometrial cells are able to produce cytokines such as IL-1 $\beta$, IL-6, IL-8, TNF- $\alpha$, which is enhanced by infiltrating immune cells (Young 2002) such as macrophages, promoting a positive feedback loop to sustain the myometrial contractility. It is important to recognise that the effect of both cytokines and pro-inflammatory agents such as LPS are dosedependent based on in vitro data; this is unlikely to reflect the reality of an in vivo system as other confounders may modify the effect. Such confounders may be innate control agents, which limit the severity of inflammation such as the production of IL-10 in response to IL-1 $\beta$ (Sadowsky et al. 2003). The production/release of such immunomodulatory cytokines may be derived from other tissues, for example decidua; this is difficult to factor into in vitro models and does limit interpretation of such data. However, some models have attempted to address this crosstalk by co-culturing with agents such as progesterone and IL-10 (Rajagopal et al. 2015).

The indirect effects of inflammation Inflammation drives the expression of CAPs, include the OTRs, PG receptors (Fig. 3) and the gap junction protein connexin 43 (Hutchings et al. 2009). 
Myometrial oxytocin system OTR mediates the effects of oxytocin (OT) on the myometrium. It is a key regulator of myometrial function. Its expression increases with advancing gestation (Fuchs et al. 1991), peaking in early labour (Rivera et al. 1990), corresponding to the clinical observation of increased uterine sensitivity to OT (Kimura et al. 1996). OT increases myometrial contractility via increases in intracellular calcium, mediated through its G-protein-coupled receptor, OTR. How inflammatory cytokines affect OTR expression is debated. Some authors show that IL- $1 \beta$ downregulates myometrial OTR expression (Rauk \& Frieve-Hoffmann 2000, Schmid et al. 2001, Helmer 2002), while others have shown that it increases OTR expression (Terzidou et al. 2006). The effect is certainly time dependent and may explain some of the conflicting data (Terzidou et al. 2006). Myometrial and decidual synthesis and release of OT was increased by IL- 6 and IL-1 $\beta$ (FriebeHoffmann et al. 2001), suggesting that the acute effects of inflammation would be to increase the activity of the myometrial OT system, consistent with the observation that acute exposure to IL-1 $\beta$ increases OT-induced contractility, but chronic exposure reduces it (Molnár et al. 1993, Rauk 2000). Intriguingly, OT has been shown to activate the NF-кB pathway, increasing the expression of several key inflammatory labour-associated genes in both myocytes and amnion cells including IL-8, IL-6, CCL-5 and COX-2 (Kim et al. 2015a). The level to which OT initiates the NF- $\mathrm{KB}$ pathway is comparable with IL- $1 \beta$ in the amnion; however, in the myometrium IL- $1 \beta$ is still the stronger inducer of the pathway (Kim et al. 2015a).

PG/PG receptors and cytokines PGs are known to initiate labour and enable contractions via cervical ripening, membrane rupture and uterine contractility. Phospholipase A2 releases arachidonic acid, which is converted into $\mathrm{PGH}_{2}$ by cycloxgenase 1 and 2 (Simmons 2004). $\mathrm{PGH}_{2}$ can be converted into the four main PGs: $\mathrm{PGE}_{2}, \mathrm{PGF}_{2 \alpha}, \mathrm{PGD}_{2}$ and prostacyclin $\left(\mathrm{PGI}_{2}\right.$ ) (Sykes et al. 2014), of which $\mathrm{PGE}_{2}$ and $\mathrm{PGF}_{2 \alpha}$ are known be potent inducers of uterine contractility in spontaneous labour (Crankshaw \& Dyal 1994). Inflammatory cytokines have long been recognised to drive PG synthesis in human myometrial cells (Hertelendy et al. 1993, Molnár et al. 1993, Pollard \& Mitchell 1996) via the activation of NFkB and MAPK, p38 (Belt et al. 1999, Bartlett et al. 1999). PGs are recognised to be pro-inflammatory and contribute to inflammatory conditions throughout the body such as in asthma (Claar et al. 2014) and cancer
(Rose et al. 2015). PGs can act as cytokine amplifiers and in particular increases activity of IL-1 $\beta$ (Aoki \& Narumiya 2012), which as mentioned plays a substantial role in initiating labour and contractility. PGs contribute to the physiological inflammatory reaction seen in labour; for example $\mathrm{PGE}_{2}$ enhances migration of leukocytes towards the cervix, which in turn leads to an increased production of IL-8 (Hertelendy \& Zakár 2004). PGF ${ }_{2 \alpha}$ indirectly can activate IL-1 $\beta$ in the decidua and consequently increase production of MMP-9 (Christiaens et al. 2008), which is known to participate in breakdown of the extracellular matrix leading to ruptured foetal membranes (Vadillo-Ortega \& Estrada-Gutiérrez 2005). Additionally, $\mathrm{PGE}_{2}$ interacts with LPS to induce IL-6, COX-2 and IL-1 $\beta$ via $\mathrm{EP}_{4}$ on macrophages (Aoki \& Narumiya 2012) indicating PGs' role in infection associated PTL.

Connexin 43 and cytokines Connexins are a family of homologous proteins (21 in humans), each of which is the product of a distinct gene (Söhl \& Willecke 2003). Connexins differ greatly in size, providing a convenient method of distinguishing them: connexin $43(\mathrm{Cx} 43)$ is $43 \mathrm{kD}$. Their best known function is to form the intercellular membrane channels of gap junctions, which allow direct sharing of small molecules between cells in a process known as gap junctional intercellular communication (Winterhager \& Kidder 2015). Cx43 is recognised as one of the contraction associated proteins (Hutchings et al. 2009).

Cx43 gap junctions are scarce in the myometrium of the non-pregnant uterus but increase in size and abundance with parturition in both humans and animals (Chow \& Lye 1994, Orsino 1996). Doring and coworkers has shown in a mouse model that ablation of $\mathrm{Cx} 43$ delays parturition. This was shown both in vitro and in vivo (Doring 2006). Cx43 is impacted by inflammation. In an in vitro model, monocytes in the presence of TNF- $\alpha$ and IFN- $\gamma$ increased protein and mRNA levels of $\mathrm{Cx} 43$ (Eugenin et al. 2003). This would increase the contractility potential of the myometrium. It is also raised in response to LPS (Chang et al. 2012) and is raised in association with PTL (Balducci et al. 1993).

$\mathrm{PGF}_{2 \alpha}$ has also been shown to increase $\mathrm{Cx} 43$ and PTGS2 expression in myocytes, the effect of which is enhanced by IL1 $\beta$ (Xu et al. 2013).

In summary, the three CAPs have been shown to be stimulated by cytokines, in particular IL-1 $\beta$, but as noted with OTR, exposure duration may have variable effect on the CAPs (this has not been studied with 
regard to PG and $\mathrm{Cx} 43$ ). Interactions between CAPs and cytokine/chemokines draw a variety of immune cells; however, the particular role of these cells are unclear, as they may be acting in an immunomodulatory capacity as opposed to the presumed inflammatory role.

\section{Future research}

Labour at term is clearly associated with inflammation. Inappropriate initiators of this inflammation seem to trigger PTL as described above. It is evident from this review that there is a multitude of factors that enable and promote the myometrium to contract (Figs 2, 3 and 4). In fact, there is a growing body of evidence to suggest that the beginning of labour may be initiated in other gestational tissues before the myometrium is involved.

Cytokines play a significant role in establishing the inflammatory environment that is associated with labour; however, there is much more to understand. Certain cytokines are repeatedly implicated in the various steps of labour; however, the exact role of each cytokine is unclear. It is understood that they are chemotactic to leukocytes, but there is little understanding of the leukocytes' exact function. Further work to identify leukocyte phenotype and function needs to be considered

Future work needs to focus on the trigger of labour as this seems to be the only question that we are unable to truly answer. By unravelling this mystery, it could be possible to identify effective therapeutic targets for those at risk of PTL. Longitudinal studies will be necessary to understand the molecular and immunological changes in normal pregnancy as this may enable identification of biomarkers and improve risk assessment. Newer high-throughput techniques such as metabolomics and proteomics could complement our current methods, and enhance our understanding of labour, which is the ultimate key in tackling PTL.

\section{Declaration of interest}

The authors declare that there is no conflict of interest that could be perceived as prejudicing the impartiality of this review.

\section{Funding}

S P S is supported by running costs from Borne, a sub-charity of CW+; N I is funded by grants from the MRC (Grant number G0501957), Westminster Medical School Research Trust and St Stephen's AIDS Trust; and M R J is funded by grants from Action Medical Research and Borne, a subcharity of CW+. In addition, this work is supported by the Imperial NIHR Biomedical Research Centre.
Author contribution statement

All authors were involved in drafting and editing the manuscript.

\section{References}

Adams Waldorf KM, Singh N, Mohan AR, Young RC, Ngo L, Das A, Tsai J, Bansal A, Paolella L, Herbert BR, et al. 2015 Uterine overdistention induces preterm labor mediated by inflammation: observations in pregnant women and nonhuman primates. American Journal of Obstetrics and Gynecology 213 830.e1-830.e19. (doi:10.1016/ j.ajog.2015.08.028)

Aluvihare VR, Kallikourdis M \& Betz AG 2004 Regulatory T cells mediate maternal tolerance to the fetus. Nature Immunology, 5 266-271. (doi:10.1038/ni1037)

Andrews WW, Hauth JC, Goldenberg RL, Gomez R, Romero R \& Cassell GH 1995 Amniotic fluid interleukin-6: correlation with upper genital tract microbial colonization and gestational age in women delivered after spontaneous labor versus indicated delivery. American Journal of Obstetrics and Gynecology 173 606-612. (doi:10.1016/00029378(95)90290-2)

Aoki T \& Narumiya S 2012 Prostaglandins and chronic inflammation. Trends in Pharmacological Sciences 33 304-311. (doi:10.1016/ j.tips.2012.02.004)

Arenas-Hernandez M, Romero R, Louis S, Hassan S, Kaye E \& Gomez-Lopez N 2016 An imbalance between innate and adaptive immune cells at the maternal-fetal interface occurs prior to endotoxin-induced preterm birth. Cellular \& Molecular Immunology 13 462-473. (doi:10.1038/cmi.2015.22)

Arici A, MacDonald PC \& Casey ML 1995 Regulation of monocyte chemotactic protein-1 gene expression in human endometrial cells in cultures. Molecular and Cellular Endocrinology 107 189-197. (doi:10.1016/0303-7207(94)03442-v)

Azziz R, Cumming J \& Naeye R 1988 Acute myometritis and chorioamnionitis during cesarean section of asymptomatic women. American Journal of Obstetrics and Gynecology 159 1137-1139. (doi:10.1016/0002-9378(88)90431-0)

Bae G, Hong J, Kim J, Park H, Jang J, Kim Y, Choi S, Oh S \& Roh C 2016 Differential immunophenotype of macrophages in acute and chronic chorioamnionitis. Journal of Perinatal Medicine [in press]. (doi:10.1515/ jpm-2015-0353)

Baggiolini M, Loetscher P \& Moser B 1995 Interleukin-8 and the chemokine family. International Journal of Immunopharmacology $\mathbf{1 7}$ 103-108. (doi:10.1016/0192-0561(94)00088-6)

Balducci J, Risek B, Gilula NB, Hand A, Egan JFX \& Vintzileos AM 1993 Gap junction formation in human myometrium: a key to preterm labor? American Journal of Obstetrics and Gynecology 168 1609-1615. (doi:10.1016/s0002-9378(11)90806-0)

Bartlett SR, Sawdy R \& Mann GE 1999 Induction of cyclooxygenase-2 expression in human myometrial smooth muscle cells by interleukin-1 $\beta$ : involvement of p38 mitogen-activated protein kinase. Journal of Physiology 520 399-406. (doi:10.1111/j.14697793.1999.00399.x)

Barzilai N, Huffman DM, Muzumdar RH \& Bartke A 2012 The critica role of metabolic pathways in aging. Diabetes 61 1315-1322. (doi:10.2337/db11-1300)

Behnia F, Taylor BD, Woodson M, Kacerovsky M, Hawkins H, Fortunato SJ, Saade GR \& Menon R 2015 Chorioamniotic membrane senescence: a signal for parturition? American Journal of Obstetrics and Gynecology 213 359.e1-359.e16. (doi:10.1016/j.ajog.2015.05.041)

Behnia F, Sheller S \& Menon R 2016 Mechanistic differences leading to infectious and sterile inflammation. American Journal of Reproductive Immunology 75 505-518. (doi:10.1111/aji.12496)

Belt AR, Baldassare JJ, Molnár M, Romero R \& Hertelendy F 1999 The nuclear transcription factor NF- $\mathrm{BB}$ mediates interleukin-1 $\beta$-induced 
expression of cyclooxygenase-2 in human myometrial cells. American Journal of Obstetrics and Gynecology 181 359-366. (doi:10.1016/s00029378(99)70562-4)

Bernal AL, Newman GE, Phizackerley PJR \& Turnbull AC 1988 Surfactant stimulates prostaglandin E production in human amnion. British Journal of Obstetrics and Gynaecology 95 1013-1017. (doi:10.1111/j.1471-0528.1988.tb06506.x)

Bernal AL, Watson SP, Phaneuf S \& Europe-Finner GN 1993 Biochemistry and physiology of preterm labour and delivery. Baillière's Clinical Obstetrics and Gynaecology 7 523-552. (doi:10.1016/s09503552(05)80447-x)

Blois SM, Kammerer U, Soto CA, Tometten MC, Shaikly V, Barrientos G, Jurd R, Rukavina D, Thomson AW, Klapp BF, et al. 2007 Dendritic cells: key to fetal tolerance? Biology of Reproduction 77 590-598. (doi:10.1095/biolreprod.107.060632)

Bollopragada S, Youssef R, Jordan F, Greer I, Norman J \& Nelson S 2009 Term labor is associated with a core inflammatory response in human fetal membranes, myometrium, and cervix. American Journal of Obstetrics and Gynecology 200 104.e1-104.e11. (doi:10.1016/ j.ajog.2008.08.032)

Bowen JM, Chamley L, Keelan JA \& Mitchell MD 2002 Cytokines of the placenta and extra-placental membranes: roles and regulation during human pregnancy and Parturition. Placenta 23 257-273. (doi:10.1053/plac.2001.0782)

Brown MB, von Chamier M, Allam AB \& Reyes L 2014 M1/M2 macrophage polarity in normal and complicated pregnancy. Frontiers in Immunology 5 606. (doi:10.3389/fimmu.2014.00606)

Buhimschi CS, Schatz F, Krikun G, Buhimschi IA \& Lockwood CJ 2010 Novel insights into molecular mechanisms of abruption-induced preterm birth. Expert Reviews in Molecular Medicine 12. (doi:10.1017/ s1462399410001675)

Casey ML \& MacDonald PC 1988 Biomolecular processes in the initiation of parturition: decidual activation. Clinical Obstetrics and Gynecology 31 533-552. (doi:10.1097/00003081-19880900000005)

Castillo-Castrejon M, Meraz-Cruz N, Gomez-Lopez N, Flores-Pliego A, Beltrán-Montoya J, Viveros-Alcaráz M \& Vadillo-Ortega F 2013 Choriodecidual cells from term human pregnancies show distinctive functional properties related to the induction of labor. American Journal of Reproductive Immunology 71 86-93. (doi:10.1111/aji.12179)

Cha J, Bartos A, Egashira M, Haraguchi H, Saito-Fujita T, Leishman E, Bradshaw H, Dey SK \& Hirota Y 2013 Combinatory approaches prevent preterm birth profoundly exacerbated by gene-environment interactions. Journal of Clinical Investigation 123 4063-4075. (doi:10.1172/jci70098)

Chaemsaithong P, Romero R, Korzeniewski SJ, Martinez-Varea A, Dong Z, Yoon BH, Hassan SS, Chaiworapongsa T \& Yeo L 2015 A rapid interleukin- 6 bedside test for the identification of intra-amniotic inflammation in preterm labor with intact membranes. Journal of Maternal-Fetal \& Neonatal Medicine 29 349-359. (doi:10.3109/147670 58.2015.1006620)

Challis JRG, Matthews SG, Gibb W \& Lye SJ 2000 Endocrine and paracrine regulation of birth at term and Preterm 1. Endocrine Reviews 21 514-550. (doi:10.1210/edrv.21.5.0407)

Chandiramani M, Seed PT, Orsi NM, Ekbote UV, Bennett PR, Shennan AH \& Tribe RM 2012 Limited relationship between cervico-vaginal fluid cytokine profiles and cervical shortening in women at high risk of spontaneous preterm birth. PLoS ONE 7 e52412. (doi:10.1371/journal. pone.0052412)

Chang EY, Zhang J, Sullivan S, Newman R \& Singh I 2012 $\mathrm{N}$-acetylcysteine prevents preterm birth by attenuating the LPS-induced expression of contractile associated proteins in an animal model. Journal of Maternal-Fetal \& Neonatal Medicine $\mathbf{2 5}$ 2395-2400. (doi:10.3109/14767058.2012.697942)
Chapman NR, Smyrnias I, Anumba DOC, Europe-Finner GN \& Robson SC 2005 Expression of the GTP-Binding protein (Gas) is repressed by the nuclear factor кB RelA Subunit in human Myometrium. Endocrinology 146 4994-5002. (doi:10.1210/en.2005-0533)

Chow L \& Lye SJ 1994 Expression of the gap junction protein connexin-43 is increased in the human myometrium toward term and with the onset of labor. American Journal of Obstetrics and Gynecology 170 788-795. (doi:10.1016/s0002-9378(94)70284-5)

Christiaens I, Zaragoza DB, Guilbert L, Robertson SA, Mitchell BF \& Olson DM 2008 Inflammatory processes in preterm and term parturition. Journal of Reproductive Immunology 79 50-57. (doi:10.1016/j.jri.2008.04.002)

Claar D, Hartert TV \& Peebles RS 2014 The role of prostaglandins in allergic lung inflammation and asthma. Expert Review of Respiratory Medicine 9 55-72. (doi:10.1586/17476348.2015.992783)

Conde-Agudelo A \& Romero R 2014 Prediction of preterm birth in twin gestations using biophysical and biochemical tests. American Journal of Obstetrics and Gynecology 211 583-595. (doi:10.1016/j. ajog.2014.07.047)

Condon JC, Jeyasuria P, Faust JM, Wilson JW \& Mendelson CR 2003 A decline in the levels of progesterone receptor coactivators in the pregnant uterus at term may antagonize progesterone receptor function and contribute to the initiation of parturition. PNAS $\mathbf{1 0 0}$ 9518-9523. (doi:10.1073/pnas.1633616100)

Condon JC, Jeyasuria P, Faust JM \& Mendelson CR 2004 Surfactant protein secreted by the maturing mouse fetal lung acts as a hormone that signals the initiation of parturition. PNAS 101 4978-4983. (doi:10.1073/pnas.0401124101)

Condon JC, Hardy DB, Kovaric K \& Mendelson CR 2006 Up-regulation of the Progesterone receptor (PR)-C Isoform in laboring Myometrium by activation of nuclear Factor- $\mathrm{kB}$ may contribute to the onset of labor through inhibition of PR function. Molecular Endocrinology 20 764-775. (doi:10.1210/me.2005-0242)

Crankshaw DJ \& Dyal R 1994 Effects of some naturally occurring prostanoids and some cyclooxygenase inhibitors on the contractility of the human lower uterine segment in vitro. Canadian Journal of Physiology and Pharmacology 72 870-874. (doi:10.1139/y94-123)

Critchley H, Kelly R, Lea R, Drudy T, Jones R \& Baird D 1996 Sex steroid regulation of leukocyte traffic in human decidua. Human Reproduction 11 2257-2262. (doi:10.1093/oxfordjournals.humrep.a019086)

Dalrymple A, Slater DM, Poston L \& Tribe RM 2004 Physiological induction of transient receptor potential canonical proteins, calcium entry channels, in human myometrium: influence of pregnancy, labor, and Interleukin-1 $\beta$. Journal of Clinical Endocrinology \& Metabolism 89 1291-1300. (doi:10.1210/jc.2003-031428)

Denison FC, Kelly RW, Calder AA \& Riley SC 1998 Cytokine secretion by human fetal membranes, decidua and placenta at term. Human Reproduction 13 3560-3565. (doi:10.1093/humrep/13.12.3560)

Dietl J 2000 The pathogenesis of pre-eclampsia: new aspects. Journal of Perinatal Medicine 28 467-471. (doi:10.1515/jpm.2000.063)

Doring B 2006 Ablation of connexin43 in uterine smooth muscle cells of the mouse causes delayed parturition. Journal of Cell Science $\mathbf{1 1 9}$ 1715-1722. (doi:10.1242/jcs.02892)

El Maradny E, Kanayama N, Halim A, Maehara K \& Terao T 1996 Stretching of fetal membranes increases the concentration of interleukin-8 and collagenase activity. American Journal of Obstetrics and Gynecology 174 843-849. (doi:10.1016/s0002-9378(96)70311-3)

Elliott CL, Slater DM, Dennes W, Poston L \& Bennett PR 2000 Interleukin 8 expression in human myometrium: changes in relation to labor onset and with gestational age. American Journal of Reproductive Immunology 43 272-277. (doi:10.1111/j.87558920.2000.430505.x)

Elliott CL, Loudon JAZ, Brown N, Slater DM, Bennett PR \& Sullivan MHF 2001 IL-1beta and IL-8 in human fetal membranes: changes with gestational age, labor, and culture conditions. American Journal of http://joe.endocrinology-journals.org

DOI: $10.1530 / \mathrm{JOE}-16-0157$
() 2016 Society for Endocrinology Printed in Great Britain 
Reproductive Immunology 46 260-267. (doi:10.1034/j.1600-0897.2001. d01-11.x)

Elovitz MA, Saunders T, Ascher-Landsberg J \& Phillippe M 2000 Effects of thrombin on myometrial contractions in vitro and in vivo. American Journal of Obstetrics and Gynecology 183 799-804. (doi:10.1067/ mob.2000.108897)

Elsasser DA, Ananth CV, Prasad V \& Vintzileos AM 2010 Diagnosis of placental abruption: relationship between clinical and histopathological findings. European Journal of Obstetrics \& Gynecology and Reproductive Biology 148 125-130. (doi:10.1016/j. ejogrb.2009.10.005)

Erlebacher A 2012 Mechanisms of T cell tolerance towards the allogeneic fetus. Nature Reviews Immunology 13 23-33. (doi:10.1038/nri3361)

Esplin MS, Romero R, Chaiworapongsa T, Kim YM, Edwin S, Gomez R, Gonzalez R \& Adashi EY 2003 Amniotic fluid levels of immunoreactive monocyte chemotactic protein-1 increase during term parturition. Journal of Maternal-Fetal \& Neonatal Medicine 14 51-56. (doi:10.1080/jmf.14.1.51.56)

Esplin MS, Peltier MR, Hamblin S, Smith S, Fausett MB, Dildy GA, Branch DW, Silver RM \& Adashi EY 2005 Monocyte chemotactic protein-1 expression is increased in human gestational tissues during term and preterm labor. Placenta 26 661-671. (doi:10.1016/j. placenta.2004.09.012)

Eugenin EA, Branes MC, Berman JW \& Saez JC 2003 TNF- $\alpha$ plus IFN- induce connexin43 expression and formation of gap Junctions between human monocytes/macrophages that enhance physiological responses. Journal of Immunology 170 1320-1328. (doi:10.4049/ jimmunol.170.3.1320)

Fang X, Wong S \& Mitchell BF 2000 Effects of LPS and IL-6 on Oxytocin receptor in non-pregnant and pregnant rat uterus. American Journal of Reproductive Immunology 44 65-72. (doi:10.1111/j.87558920.2000.440201.x)

Fest S, Aldo PB, Abrahams VM, Visintin I, Alvero A, Chen R, Chavez SL, Romero R \& Mor G 2007 Trophoblast? Macrophage interactions: a regulatory network for the protection of pregnancy. American Journal of Reproductive Immunology 57 55-66. (doi:10.1111/j.16000897.2006.00446.x)

Fortunato S, Menon R, Lombardi S \& LaFleur B 2001 Interleukin-10 inhibition of gelatinases in fetal membranes: therapeutic implications in preterm premature rupture of membranes. Obstetrics and Gynecology 98 284-288. (doi:10.1016/s0029-7844(01)01441-7)

Friebe-Hoffmann U, Chiao JP \& Rauk P 2001 Effect of IL-1beta and IL-6 on oxytocin secretion in human uterine smooth muscle cells. American Journal of Reproductive Immunology 46 226-231. (doi:10.1034/j.1600-0897.2001.d01-6.x)

Friebe-Hoffmann U, Baston DM, Hoffmann TK, Chiao JP \& Rauk PN 2007 The influence of interleukin- $1 \beta$ on oxytocin signalling in primary cells of human decidua. Regulatory Peptides 142 78-85. (doi:10.1016/j. regpep.2007.01.012)

Fuchs A-R, Romero R, Keefe D, Parra M, Oyarzun E \& Behnke E 1991 Oxytocin secretion and human parturition: pulse frequency and duration increase during spontaneous labor in women. American Journal of Obstetrics and Gynecology 165 1515-1523. (doi:10.1016/0002-9378(91)90399-c)

Gniesinger G, Saleh L, Bauer S, Husslein P \& Knofler M 2001 Production of pro- and anti-inflammatory cytokines of human placental trophoblasts in response to pathogenic bacteria. Reproductive Sciences 8 334-340. (doi:10.1177/107155760100800605)

Golightly E, Jabbour HN \& Norman JE 2011 Endocrine immune interactions in human parturition. Molecular and Cellular Endocrinology 335 52-59. (doi:10.1016/j.mce.2010.08.005)

Gomez-Lopez N, Estrada-Gutierrez G, Jimenez-Zamudio L, Vega-Sanchez R \& Vadillo-Ortega F 2009 Fetal membranes exhibit selective leukocyte chemotaxic activity during human labor. Journal of Reproductive Immunology 80 122-131. (doi:10.1016/j. jri.2009.01.002)
Gomez-Lopez N, Laresgoiti-Servitje E, Olson DM, Estrada-Gutierrez G \& Vadillo-Ortega F 2010 The role of chemokines in term and premature rupture of the fetal Membranes: a review. Biology of Reproduction 82 809-814. (doi:10.1095/biolreprod.109.080432)

Gomez-Lopez N, Tanaka S, Zaeem Z, Metz G \& Olson D 2013 Maternal circulating leukocytes display early chemotactic responsiveness during late gestation. BMC Pregnancy and Childbirth 13 (Suppl 1) S8. (doi:10.1186/1471-2393-13-s1-s8)

Gomez-Lopez N, Romero R, Plazyo O, Panaitescu B, Furcron A, Miller D, Roumayah T, Flom E \& Hassan S 2016 Intra-amniotic administration of HMGB1 induces spontaneous preterm labor and birth. American Journal of Reproductive Immunology 75 3-7. (doi:10.1111/aji.12443)

Gonzalez JM, Franzke C-W, Yang F, Romero R \& Girardi G 2011 Complement activation triggers metalloproteinases release inducing cervical remodeling and Preterm birth in mice. American Journal of Pathology 179 838-849. (doi:10.1016/j.ajpath.2011.04.024)

Goodwin VJ, Sato TA, Mitchell MD \& Keelan JA 1998 Anti-inflammatory effects of interleukin-4, interleukin-10, and transforming growth factor- $\beta$ on human placental cells in vitro. American Journal of Reproductive Immunology 40 319-325. (doi:10.1111/j.1600-0897.1998. tb00060.x)

Griffith JW, Sokol CL \& Luster AD 2014 Chemokines and chemokine receptors: positioning cells for host defense and immunity. Annual Review of Immunology 32 659-702. (doi:10.1146/annurevimmunol-032713-120145)

Gubbels Bupp MR 2015 Sex, the aging immune system, and chronic disease. Cellular Immunology 294 102-110. (doi:10.1016/j. cellimm.2015.02.002)

Hamill N, Romero R, Gotsch F, Kusanovic JP, Edwin S, Erez O, Gabor Than N, Mittal P, Espinoza J, Friel LA, Vaisbuch E, et al. 2008 Exodus-1 (CCL20): evidence for the participation of this chemokine in spontaneous labor at term, preterm labor, and intrauterine infection. Journal of Perinatal Medicine 36 217-227. (doi:10.1515/ jpm.2008.034)

Hamilton S, Oomomian Y, Stephen G, Shynlova O, Tower CL, Garrod A, Lye SJ \& Jones RL 2011 Macrophages infiltrate the human and rat decidua during term and preterm labor: evidence that decidual inflammation precedes labor. Biology of Reproduction 86 39-39. (doi:10.1095/biolreprod.111.095505)

Hamilton SA, Tower CL \& Jones RL 2013 Identification of chemokines associated with the recruitment of decidual Leukocytes in human labour: potential novel targets for preterm labour. PLOS ONE 8 e56946. (doi:10.1371/journal.pone.0056946)

Han CS, Schatz F \& Lockwood CJ 2011 Abruption-associated prematurity. Clinics in Perinatology 38 407-421. (doi:10.1016/j.clp.2011.06.001)

Hardy DB, Janowski BA, Corey DR \& Mendelson CR 2006 Progesterone receptor plays a major antiinflammatory role in human myometrial cells by antagonism of nuclear factor- $\mathrm{kB}$ activation of cyclooxygenase 2 expression. Molecular Endocrinology 20 2724-2733. (doi:10.1210/ me.2006-0112)

Harger JH, Hsing AW, Tuomala RE, Gibbs RS, Mead PB, Eschenbach DA, Eric Knox G \& Frank Polk B 1990 Risk factors for preterm premature rupture of fetal membranes: a multicenter case-control study. American Journal of Obstetrics and Gynecology 163 130-137. (doi:10.1016/s0002-9378(11)90686-3)

Haugueldemouzon S \& Guerremillo M 2006 The placenta cytokine network and inflammatory signals. Placenta 27 794-798. (doi:10.1016/j.placenta.2005.08.009)

Hebisch G, Grauaug AA, Neumaier-Wagner PM, Stallmach T, Huch A \& Huch R 2001 The relationship between cervical dilatation, interleukin-6 and interleukin-8 during term labor. Acta Obstetricia et Gynecologica Scandinavica 80 840-848. (doi:10.1034/j.16000412.2001.080009840.x)

Helmer H 2002 Production of oxytocin receptor and cytokines in primary uterine smooth muscle cells cultivated under inflammatory

Published by Bioscientifica Ltd. 
conditions. Journal of the Society for Gynecologic Investigation 9 15-21. (doi:10.1016/s1071-5576(01)00142-3)

Heng YJ, Pennell CE, Chua HN, Perkins JE \& Lye SJ 2014 Whole blood gene expression profile associated with spontaneous preterm birth in women with threatened preterm labor. PLOS ONE 9 e96901. (doi:10.1371/journal.pone.0096901)

Hertelendy F \& Zakár T 2004 Prostaglandins and the myometrium and cervix. Prostaglandins, Leukotrienes and Essential Fatty Acids 70 207-222. (doi:10.1016/j.plefa.2003.04.009)

Hertelendy F, Romero R, Molnar M, Todd H \& Baldassare JJ 1993 Cytokine-initiated signal transduction in human myometrial cells. American Journal of Reproductive Immunology 30 49-57. (doi:10.1111/j.1600-0897.1993.tb00601.x)

Hirsch E, Filipovich Y \& Mahendroo M 2006 Signaling via the type I IL-1 and TNF receptors is necessary for bacterially induced preterm labor in a murine model. American Journal of Obstetrics and Gynecology 194 1334-1340. (doi:10.1016/j.ajog.2005.11.004)

Hirst JJ, Teixeira FJ, Zakar T \& Olson DM 1995 Prostaglandin endoperoxide-h synthase-1 and -2 messenger ribonucleic acid levels in human amnion with spontaneous labor onset. Journal of Clinical Endocrinology \& Metabolism 80 517-523. (doi:10.1210/jcem.80.2.7852513)

Hua R, Pease JE, Sooranna SR, Viney JM, Nelson SM, Myatt L, Bennett PR \& Johnson MR 2012 Stretch and inflammatory cytokines drive myometrial chemokine expression via NF-кB activation. Endocrinology 153 481-491. (doi:10.1210/en.2011-1506)

Hutchings G, Williams O, Cretoiu D \& Ciontea SM 2009 Myometrial interstitial cells and the coordination of myometrial contractility. Journal of Cellular and Molecular Medicine 13 4268-4282. (doi:10.1111/ j.1582-4934.2009.00894.x)

Hutchinson JL, Rajagopal SP, Yuan M \& Norman JE 2013 Lipopolysaccharide promotes contraction of uterine myocytes via activation of Rho/ROCK signaling pathways. FASEB Journal $\mathbf{2 8}$ 94-105. (doi:10.1096/fj.13-237040)

Idriss HT \& Naismith JH 2000 TNF? And the TNF receptor superfamily: structure-function relationship(s). Microscopy Research and Technique 50 184-195. (doi:10.1002/1097-0029(20000801)50:3<184::aidjemt2>3.0.co;2-h)

Jones RL, Kelly RW \& Critchley HO 1997 Chemokine and cyclooxygenase- 2 expression in human endometrium coincides with leukocyte accumulation. Human Reproduction 12 1300-1306. (doi:10.1093/humrep/12.6.1300)

Jung EY, Park JW, Ryu A, Lee SY, Cho S \& Park KH 2015 Prediction of impending preterm delivery based on sonographic cervical length and different cytokine levels in cervicovaginal fluid in preterm labor. Journal of Obstetrics and Gynaecology Research 42 158-165. (doi:10.1111/jog.12882)

Keelan JA, Marvin KW, Sato TA, Coleman M, McCowan LME \& Mitchell MD 1999 Cytokine abundance in placental tissues: evidence of inflammatory activation in gestational membranes with term and preterm parturition. American Journal of Obstetrics and Gynecology 181 1530-1536. (doi:10.1016/s0002-9378(99)70400-x)

Keelan JA, Blumenstein M, Helliwell RJA, Sato TA, Marvin KW \& Mitchell MD 2003 Cytokines, prostaglandins and parturition-a review. Placenta 24 S33-S46. (doi:10.1053/plac.2002.0948)

Kemp B, Menon R, Fortunato S, Winkler M, Maul H \& Rath W $2002 a$ Quantitation and localization of inflammatory cytokines interleukin- 6 and interleukin- 8 in the lower uterine segment during cervical dilatation. Journal of Assisted Reproduction and Genetics 19 215-219. (doi:10.1023/A:1015354701668)

Kemp B, Winkler M, Maas A, Maul H, Ruck P, Reineke T \& Rath W $2002 b$ Cytokine concentrations in the amniotic fluid during parturition at term: correlation to lower uterine segment values and to labor. Acta Obstetricia et Gynecologica Scandinavica 81 938-942. (doi:10.1034/ j.1600-0412.2002.811007.x)

Kim SH, MacIntyre DA, Firmino Da Silva M, Blanks AM, Lee YS, Thornton S, Bennett PR \& Terzidou V 2015a Oxytocin activates
NF-кB-mediated inflammatory pathways in human gestational tissues. Molecular and Cellular Endocrinology 403 64-77. (doi:10.1016/ j.mce.2014.11.008)

Kim C, Romero R, Chaemsaithong P, Chaiyasit N, Yoon B \& Kim Y 2015b Acute chorioamnionitis and funisitis: definition, pathologic features, and clinical significance. American Journal of Obstetrics and Gynecology 213 S29-S52. (doi:10.1016/j.ajog.2015.08.040)

Kimura T, Takemura M, Nomura S, Nobunaga T, Kubota Y, Inoue T, Hashimoto K, Kumazawa I, Ito Y, Ohashi K, et al. 1996 Expression of oxytocin receptor in human pregnant myometrium. Endocrinology 137 780-785. (doi:10.1210/endo.137.2.8593830)

Krishnan SM, Sobey CG, Latz E, Mansell A \& Drummond GR 2014 IL-1 $\beta$ and IL-18: inflammatory markers or mediators of hypertension? British Journal of Pharmacology 171 5589-5602. (doi:10.1111/ bph.12876)

Kuon RJ, Strowitzki T, Sohn C, Daniel V \& Toth B 2015 Immune profiling in patients with recurrent miscarriage. Journal of Reproductive Immunology 108 136-141. (doi:10.1016/j.jri.2015.01.007)

La Rocca C, Carbone F, Longobardi S \& Matarese G 2014 The immunology of pregnancy: regulatory $\mathrm{T}$ cells control maternal immune tolerance toward the fetus. Immunology Letters 162 41-48. (doi:10.1016/j.imlet.2014.06.013)

Laham N, Brennecke SP, Bendtzen K \& Rice GE 1994 Tumour necrosis factor a during human pregnancy and labour: maternal plasma and amniotic fluid concentrations and release from intrauterine tissues. European Journal of Endocrinology 131 607-614. (doi:10.1530/ eje.0.1310607)

Laham N, Rice GE, Bishop GJ, Ransome C \& Brennecke SP 1993 Interleukin 8 concentrations in amniotic fluid and peripheral venous plasma during human pregnancy and parturition. European Journal of Endocrinology 129 220-224. (doi:10.1530/acta.0.1290220)

Lee Y-H, Shynlova O \& Lye SJ 2014 Stretch-induced human myometrial cytokines enhance immune cell recruitment via endothelial activation. Cellular and Molecular Immunology 12 231-242. (doi:10.1038/cmi.2014.39)

Lei K, Chen L, Georgiou EX, Sooranna SR, Khanjani S, Brosens JJ, Bennett PR \& Johnson MR 2012 Progesterone acts via the nuclear Glucocorticoid receptor to suppress IL-1 $\beta$-induced COX-2 expression in human term myometrial cells. PLoS ONE 7 e50167. (doi:10.1371/ journal.pone.0050167)

Lei K, Georgiou EX, Chen L, Yulia A, Sooranna SR, Brosens JJ, Bennett PR \& Johnson MR 2015 Progesterone and the repression of myometrial inflammation: the roles of MKP-1 and the AP-1 system. Molecular Endocrinology 29 1454-1467. (doi:10.1210/me.2015-1122)

Lockwood CJ, Toti P, Arcuri F, Paidas M, Buchwalder L, Krikun G \& Schatz F 2005 Mechanisms of abruption-induced premature rupture of the fetal membranes. American Journal of Pathology 167 1443-1449. (doi:10.1016/s0002-9440(10)61230-8)

Loudon JAZ 2004 Mechanical stretch of human uterine smooth muscle cells increases IL-8 mRNA expression and peptide synthesis. Molecular Human Reproduction 10 895-899. (doi:10.1093/molehr/gah112)

Lyall F 2002 Expression of gs $\alpha$, connexin-43, connexin-26, and EP1, 3 , and 4 receptors in myometrium of prelabor singleton versus multiple gestations and the effects of mechanical stretch and steroids on gsa. Journal of the Society for Gynecologic Investigation 9 299-307. (doi:10.1016/s1071-5576(02)00175-2)

Lytinas M, Kempuraj D, Huang M, Boucher W, Esposito P \& Theoharides TC 2003 Acute stress results in skin corticotropinreleasing hormone secretion, mast cell activation and vascular permeability, an effect mimicked by Intradermal corticotropinreleasing hormone and inhibited by histamine-1 receptor antagonists. International Archives of Allergy and Immunology 130 224-231. (doi:10.1159/000069516)

Mackler AM 1999 Macrophage trafficking in the uterus and cervix precedes Parturition in the mouse. Biology of Reproduction 61 879-883. (doi:10.1095/biolreprod61.4.879) 
Mackler AM 2003 Effects of endotoxin and macrophage-related cytokines on the contractile activity of the gravid murine uterus. Biology of Reproduction 69 1165-1169. (doi:10.1095/ biolreprod.103.015586)

Manbe Y, Manabe A \& Takahashi A 1982 F prostaglandin levels in amniotic fluid during balloon-induced cervical softening and labor at term. Prostaglandins 23 247-256. (doi:10.1016/00906980(82)90052-1)

Manegold-Brauer G, Hoesli I, Brauer H \& Beikler T 2014 [Periodontal diseases-a review on the association between maternal periodontitis and adverse pregnancy outcome]. Zeitschrift für Geburtshilfe und Neonatologie 218 248-253.

Martinon F, Mayor A \& Tschopp J 2009 The inflammasomes: guardians of the body. Annual Review of Immunology 27 229-265. (doi:10.1146/ annurev.immunol.021908.132715)

Masson L, Arnold K, Little F, Mlisana K, Lewis D, Mkhize N, Gamieldien H, Ngcapu S, Johnson L, Lauffenburger D, et al. 2016 Inflammatory cytokine biomarkers to identify women with asymptomatic sexually transmitted infections and bacterial vaginosis who are at high risk of HIV infection. Sexually Transmitted Infections 92 186-193. (doi:10.1136/sextrans-2015-052072)

Matta P, Lockwood CJ, Schatz F, Krikun G, Rahman M, Buchwalder L \& Norwitz ER 2007 Thrombin regulates monocyte chemoattractant protein-1 expression in human first trimester and term decidual cells. American Journal of Obstetrics and Gynecology 196 268.e1-268.e8. (doi:10.1016/j.ajog.2006.09.008)

Meeusen ENT, Bischof RJ \& Lee C-S 2001 Comparative t-cell responses during pregnancy in large animals and humans. American Journal of Reproductive Immunology 46 169-179. (doi:10.1111/j.87558920.2001.460208.x)

Melgert BN, Spaans F, Borghuis T, Klok PA, Groen B, Bolt A, de Vos P, van Pampus MG, Wong TY, van Goor H, et al. 2012 Pregnancy and preeclampsia affect monocyte subsets in humans and rats. PLOS ONE 7 e45229. (doi:10.1371/journal.pone.0045229)

Mendelson CR 2009 Minireview: fetal-maternal hormonal signaling in pregnancy and labor. Molecular Endocrinology 23 947-954. (doi:10.1210/me.2009-0016)

Menzies FM, Higgins CA, Shepherd MC, Nibbs RJ \& Nelson SM 2011 Mast cells reside in myometrium and cervix, but are dispensable in mice for successful pregnancy and labor. Immunology and Cell Biology 90 321-329. (doi:10.1038/icb.2011.40)

Menzies FM, Khan AH, Higgins CA, Nelson SM \& Nibbs RJB 2012 The chemokine receptor CCR2 is not required for successful initiation of labor in mice. Biology of Reproduction 86 118-118. (doi:10.1095/ biolreprod.111.094631)

Mesiano S, Chan E-C, Fitter JT, Kwek K, Yeo G \& Smith R 2002 Progesterone withdrawal and estrogen activation in human parturition are coordinated by progesterone receptor A expression in the myometrium. Journal of Clinical Endocrinology \& Metabolism 87 2924-2930. (doi:10.1210/jcem.87.6.8609)

Mittal P, Romero R, Tarca AL, Gonzalez J, Draghici S, Xu Y, Dong Z, Nhan-Chang C-L, Chaiworapongsa T, Lye S, et al. 2010 Characterization of the myometrial transcriptome and biological pathways of spontaneous human labor at term. Journal of Perinatal Medicine 38 617-643. (doi:10.1515/jpm.2010.097)

Molnár M, Romero R \& Hertelendy F 1993 Interleukin-1 and tumor necrosis factor stimulate arachidonic acid release and phospholipid metabolism in human myometrial cells. American Journal of Obstetrics and Gynecology 169 825-829. (doi:10.1016/00029378(93)90011-7)

Moraitis AA, Cordeaux Y, Charnock-Jones DS \& Smith GCS 2015 The effect of an Oxytocin receptor antagonist (Retosiban, GSK221149A) on the response of human myometrial explants to prolonged mechanical stretch. Endocrinology 156 3511-3516. (doi:10.1210/ en.2015-1378)
Muñoz-Espín D \& Serrano M 2014 Cellular senescence: from physiology to pathology. Nature Reviews Molecular Cell Biology 15 482-496. (doi:10.1038/nrm3823)

Murphy S, Hanna N, Fast L, Shaw S, Berg G, Padbury J, Romero R \& Sharma S 2008 Evidence for participation of uterine natural killer cells in the mechanisms responsible for spontaneous preterm labor and delivery. American Journal of Obstetrics and Gynecology 200 308.e1-308.e9. (doi:10.1016/j.ajog.2008)

Nath CA, Ananth CV, Smulian JC, Shen-Schwarz S \& Kaminsky L 2007 Histologic evidence of inflammation and risk of placental abruption. American Journal of Obstetrics and Gynecology 197 319.e1-319.e6. (doi:10.1016/j.ajog.2007.06.012)

Oger S, Méhats C, Dallot E, Ferré F \& Leroy M-J 2002 Interleukin-1 $\beta$ induces phosphodiesterase $4 \mathrm{~B} 2$ expression in human myometrial cells through a prostaglandin E 2 - and Cyclic Adenosine 3',5'-monophosphatedependent pathway. Journal of Clinical Endocrinology \& Metabolism 87 5524-5531. (doi:10.1210/jc.2002-020575)

Orsino A 1996 Connexin-26 and connexin-43 are differentially expressed and regulated in the rat myometrium throughout late pregnancy and with the onset of labor. Endocrinology 137 1545-1553. (doi:10.1210/ en.137.5.1545)

Osmers R 1995 Interleukin-8 synthesis and the onset of labor. Obstetrics \& Gynecology 86 223-229. (doi:10.1016/0029-7844(95)93704-4)

Papatheodorou DC, Karagiannidis LK, Paltoglou G, Margeli A, Kaparos G, Valsamakis G, Chrousos GP, Creatsas G \& Mastorakos G 2013 Pulsatile Interleukin-6 leads CRH secretion and is associated with myometrial contractility during the active phase of term human labor. Journal of Clinical Endocrinology \& Metabolism 98 4105-4112. (doi:10.1210/jc.2012-4023)

Parthiban P 2015 Toll-like receptors: a key marker for periodontal disease and preterm birth - a contemporary review. Journal of Clinical and Diagnostic Research 9 ZE14-ZE17. (doi:10.7860/jcdr/2015/14143.6526)

Pehlivanoglu B, Bayrak S \& Dogan M 2013 A close look at the contraction and relaxation of the myometrium; the role of calcium. Journal of the Turkish-German Gynecological Association 14 230-234. (doi:10.5152/ jtgga.2013.67763)

Peltier MR 2003 Immunology of term and preterm labor. Reproductive Biology and Endocrinology 1 122. (doi:10.1186/1477-7827-1-122)

Pollard JK \& Mitchell MD 1996 Effects of gestational age on prostaglandin production and its regulation in human myometrial cells. Journal of Maternal-Fetal and Neonatal Medicine 5 93-98. (doi:10.3109/14767059609025405)

Proost P, Wuyts A \& Damme V 1996 Human monocyte chemotactic proteins-2 and -3: structural and functional comparison with MCP-1. Journal of Leukocyte Biology 59 67-74.

Racicot K, Kwon J.Y, Aldo P, Silasi M \& Mor G 2014 Understanding the complexity of the immune system during pregnancy. American Journal of Reproductive Immunology 72 107-116. (doi:10.1111/aji.12289)

Rajagopal SP, Hutchinson JL, Dorward DA, Rossi AG \& Norman JE 2015 Crosstalk between monocytes and myometrial smooth muscle in culture generates synergistic pro-inflammatory cytokine production and enhances myocyte contraction, with effects opposed by progesterone. Molecular Human Reproduction 21 672-686. (doi:10.1093/molehr/gav027)

Ramhorst RE, García VE, Corigliano A, Rabinovich GA \& Fainboim L 2004 Identification of RANTES as a novel immunomodulator of the maternal allogeneic response. Clinical Immunology 110 71-80. (doi:10.1016/j.clim.2003.09.011)

Rauk PN 2000 Oxytocin signaling in human myometrium is impaired by prolonged exposure to Interleukin-1. Biology of Reproduction $\mathbf{6 3}$ 846-850. (doi:10.1095/biolreprod63.3.846)

Rauk PN \& Friebe-Hoffmann U 2000 Interleukin-1beta down-regulates the oxytocin receptor in cultured Uterine smooth muscle cells. American Journal of Reproductive Immunology 43 85-91. (doi:10.1111/ j.8755-8920.2000.430204.x) http://joe.endocrinology-journals.org

DOI: $10.1530 / J O E-16-0157$
() 2016 Society for Endocrinology Printed in Great Britain
Published by Bioscientifica Ltd 
Ravanos K, Dagklis T, Petousis S, Margioula-Siarkou C \& Prapas Y 2015 Factors implicated in the initiation of human parturition in term and preterm labor: a review. Gynecological Endocrinology 31 679-683. (doi:10.3109/09513590.2015.1076783)

Reichman D, Laufer MR \& Robinson BK 2009 Pregnancy outcomes in unicornuate uteri: a review. Fertility and Sterility 91 1886-1894. (doi:10.1016/j.fertnstert.2008.02.163)

Reinl EL \& England SK 2015 Fetal-to-maternal signaling to initiate parturition. Journal of Clinical Investigation 125 2569-2571. (doi:10.1172/jci82576)

Rinaldi SF, Catalano RD, Wade J, Rossi AG \& Norman JE 2014 Decidual neutrophil infiltration is not required for preterm birth in a mouse model of infection-induced preterm labor. Journal of Immunology 192 2315-2325. (doi:10.4049/jimmunol.1302891)

Rivera J, Bernal AL, Varney M \& Watson SP 1990 Inositol 1, 4,5-trisphosphate and oxytocin binding in human myometrium. Endocrinology 127 155-162. (doi:10.1210/endo-127-1-155)

Rodriguez M 1992 Polyhydramnios: does reducing the amniotic fluid volume decrease the incidence of prematurity? Clinics in Perinatology 19 359-366.

Romero R, Parvizi S, Oyarzun E, Mazor M, Wu Y, Avila C, Athanassiadis A \& Mitchell M 1990 Amniotic fluid interleukin-1 in spontaneous labor at term. Journal of Reproductive Medicine 35 235-238.

Romero R, Ceska M, Avila C, Mazor M, Behnke E \& Lindley I 1991 Neutrophil attractant/activating peptide-1/interleukin-8 in term and preterm parturition. American Journal of Obstetrics and Gynecology 165 813-820. (doi:10.1016/0002-9378(91)90422-n)

Romero R, Gomez R, Chaiworapongsa T, Conoscenti G, Cheol Kim J \& Mee Kim Y 2001 The role of infection in preterm labour and delivery. Paediatric and Perinatal Epidemiology 15 41-56. (doi:10.1046/j.13653016.2001.00007.x)

Romero R, Dey SK \& Fisher SJ 2014a Preterm labor: one syndrome, many causes. Science 345 760-765. (doi:10.1126/science.1251816)

Romero R, Miranda J, Chaiworapongsa T, Korzeniewski S, Chaemsaithong P, Gotsch F, Dong Z, Ahmed A, Yoon B, Hassan S, et al. $2014 b$ Prevalence and clinical significance of sterile intraamniotic inflammation in patients with preterm labor and intact membranes. American Journal of Reproductive Immunology 72 458-474. (doi:10.1111/aji.12296)

Romero R, Grivel J, Tarca A, Chaemsaithong P, Xu Z, Fitzgerald W, Hassan S, Chaiworapongsa T \& Margolis L 2015 Evidence of perturbations of the cytokine network in preterm labor. American Journal of Obstetrics and Gynaecology 213 836.e1-836.e18. (doi:10.1016/j.ajog.2015.07.037)

Rose D, Gracheck P \& Vona-Davis L 2015 The interactions of obesity, inflammation and insulin resistance in breast cancer. Cancers 7 2147-2168. (doi:10.3390/cancers7040883)

Sadowsky D, Novy M, Witkin S \& Gravett M 2003 Dexamethasone or interleukin-10 blocks interleukin-1beta-induced uterine contractions in pregnant rhesus monkeys. American Journal of Obstetrics and Gynecology 188 252-263. (doi:10.1067/mob.2003.70)

Saito S, Kasahara T, Kato Y, Ishihara Y \& Ichijo M 1993 Elevation of amniotic fluid interleukin 6 (IL-6), IL-8 and granulocyte colony stimulating factor (G-CSF) in term and preterm parturition. Cytokine 5 81-88. (doi:10.1016/1043-4666(93)90027-3)

Salafia CM, López-Zeno J, Sherer DM, Whittington SS, Minior VK \& Vintzileos AM 1995 Histologic evidence of old intrauterine bleeding is more frequent in prematurity. American Journal of Obstetrics and Gynecology 173 1065-1070. (doi:10.1016/00029378(95)91327-0)

Sasaki A, Shinkawa O, Margioris AN, Liotta AS, Sato S, MurakamiI O, Go M, Shimizu Y, Hanew K \& Yoshinaga K 1987 Immunoreactive corticotropin-releasing hormone in human plasma during pregnancy, labor, and delivery. Journal of Clinical Endocrinology \& Metabolism 64 224-229. (doi:10.1210/jcem-64-2-224)
Schmid B, Wong S \& Mitchell BF 2001 Transcriptional regulation of oxytocin receptor by interleukin-1 $\beta$ and interleukin-6. Endocrinology 142 1380-1385. (doi:10.1210/endo.142.4.8107)

Shynlova O, Tsui P, Dorogin A \& Lye SJ 2008 Monocyte chemoattractant protein-1 (CCL-2) integrates mechanical and endocrine signals that mediate term and preterm labor. Journal of Immunology $\mathbf{1 8 1}$ 1470-1479. (doi:10.4049/jimmunol.181.2.1470)

Shynlova O, Lee Y-H, Srikhajon K \& Lye SJ 2012a Physiologic uterine inflammation and labor onset: integration of endocrine and mechanical signals. Reproductive Sciences 20 154-167. (doi:10.1177/1933719112446084)

Shynlova O, Nedd-Roderique T, Li Y, Dorogin A \& Lye SJ $2012 b$ Myometrial immune cells contribute to term parturition, preterm labour and post-partum involution in mice. Journal of Cellular and Molecular Medicine 17 90-102. (doi:10.1111/j.1582 4934.2012.01650.x)

Shynlova O, Dorogin A, Li Y \& Lye S 2014 Inhibition of infectionmediated preterm birth by administration of broad spectrum chemokine inhibitor in mice. Journal of Cellular and Molecular Medicine 18 1816-1829. (doi:10.1111/jcmm.12307)

Simmons DL 2004 Cyclooxygenase isozymes: the biology of prostaglandin synthesis and inhibition. Pharmacological Reviews 56 387-437. (doi:10.1124/pr.56.3.3)

Sindram-Trujillo A, Scherjon S, Hulst-van van, Kanhai H, Roelen D \& Claas F 2004 Comparison of decidual leukocytes following spontaneous vaginal delivery and elective cesarean section in uncomplicated human term pregnancy. Journal of Reproductive Immunology 62 125-137. (doi:10.1016/j.jri.2003.11.007)

Smith R 2007 Parturition. New England Journal of Medicine 356 271-283. (doi:10.1056/nejmra061360)

Söhl G \& Willecke K 2003 An update on connexin genes and their nomenclature in mouse and man. Cell Communication \& Adhesion 10 173-180. (doi:10.1080/714040423)

Somerset DA, Zheng Y, Kilby MD, Sansom DM \& Drayson MT 2004 Normal human pregnancy is associated with an elevation in the immune suppressive CD25+CD4+ regulatory t-cell subset. Immunology 112 38-43. (doi:10.1111/j.1365-2567.2004.01869.x)

Sooranna SR 2004 Mechanical stretch activates type 2 cyclooxygenase via activator protein-1 transcription factor in human myometrial cells. Molecular Human Reproduction 10 109-113. (doi:10.1093/molehr/ gah021)

Sooranna SR, Engineer N, Loudon JAZ, Terzidou V, Bennett PR \& Johnson MR 2005 The mitogen-activated protein Kinase dependent expression of prostaglandin $\mathrm{H}$ synthase- 2 and interleukin- 8 messenger ribonucleic acid by Myometrial cells: the differential effect of stretch and Interleukin-1 $\beta$. Journal of Clinical Endocrinology \& Metabolism 90 3517-3527. (doi:10.1210/ jc.2004-1390)

Srikhajon K, Shynlova O, Preechapornprasert A, Chanrachakul B \& Lye S 2014 A new role for monocytes in modulating myometrial inflammation during human labor. Biology of Reproduction 91 10-10. (doi:10.1095/biolreprod.113.114975)

Steinborn A, Schmitt E, Kisielewicz A, Rechenberg S, Seissler N, Mahnke K, Schaier M, Zeier M \& Sohn C 2011 Pregnancy-associated diseases are characterized by the composition of the systemic regulatory T cell (Treg) pool with distinct subsets of Tregs. Clinical \& Experimental Immunology 167 84-98. (doi:10.1111/j.13652249.2011.04493.x)

Sykes L, MacIntyre DA, Teoh TG \& Bennett PR 2014 Anti-inflammatory prostaglandins for the prevention of preterm labour. Reproduction 148 R29-R40. (doi:10.1530/rep-13-0587)

Tang M-X, Hu X-H, Liu Z-Z, Kwak-Kim J \& Liao A-H 2015 What are the roles of macrophages and monocytes in human pregnancy? Journal of Reproductive Immunology 112 73-80. (doi:10.1016/ j.jri.2015.08.001) http://joe.endocrinology-journals.org

DOI: 10.1530/JOE-16-0157
() 2016 Society for Endocrinology Printed in Great Britain 
Tattersall M, Cordeaux Y, Charnock-Jones DS \& Smith GCS 2012 Expression of gastrin-releasing peptide is increased by prolonged stretch of human myometrium, and antagonists of its receptor inhibit contractility. Journal of Physiology 590 2081-2093. (doi:10.1113/ jphysiol.2012.228239)

Terzidou V, Sooranna SR, Kim LU, Thornton S, Bennett PR \& Johnson MR 2005 Mechanical stretch up-regulates the human oxytocin receptor in primary human uterine myocytes. Journal of Clinical Endocrinology \& Metabolism 90 237-246. (doi:10.1210/jc.2004-0277)

Terzidou V, Lee Y, Lindström T, Johnson M, Thornton S \& Bennett PR 2006 Regulation of the human oxytocin receptor by nuclear Factor- $\mathrm{B}$ and CCAAT/enhancer-binding protein- $\beta$. Journal of Clinical Endocrinology \& Metabolism 91 2317-2326. (doi:10.1210/ jc.2005-2649)

Thaxton JE \& Sharma S 2010 Interleukin-10: a multi-faceted agent of pregnancy. American Journal of Reproductive Immunology 63 482-491. (doi:10.1111/j.1600-0897.2010.00810.x)

Thomson AJ, Telfer JF, Young A, Campbell S, Stewart CJR, Cameron IT, Greer IA \& Norman JE 1999 Leukocytes infiltrate the myometrium during human parturition: further evidence that labour is an inflammatory process. Human Reproduction 14 229-236. (doi:10.1093/ humrep/14.1.229)

Tilburgs T, Scherjon S, van der Mast BJ, Haasnoot G, Versteeg-V D, Roelen D, van Rood JJ \& Claas F 2009 Fetal-maternal HLA-C mismatch is associated with decidual $\mathrm{T}$ cell activation and induction of functional T regulatory cells. Journal of Reproductive Immunology $\mathbf{8 2}$ 148-157. (doi:10.1016/j.jri.2009.05.003)

Timmons BC 2006 Timing of neutrophil activation and expression of proinflammatory markers do not support a role for neutrophils in cervical ripening in the mouse. Biology of Reproduction 74 236-245. (doi:10.1095/biolreprod.105.044891)

Toyoshima K, Narahara H, Furukawa M, Frenkel R \& Johnston J 1995 Platelet-activating factor. Role in fetal lung development and relationship to normal and premature labor. Clinics in Perinatology 22 263-280.

Tribe RM 2002 Interleukin-1 induces calcium transients and enhances basal and store operated calcium entry in human myometrial smooth muscle. Biology of Reproduction 68 1842-1849. (doi:10.1095/ biolreprod.102.011403)

Vadillo-Ortega F \& Estrada-Gutiérrez G 2005 Role of matrix metalloproteinases in preterm labour. British Journal of Obstetrics \& Gynaecology 112 19-22. (doi:10.1111/j.14710528.2005.00579.x)

Venihaki M, Dikkes P, Carrigan A \& Karalis KP 2001 Corticotropinreleasing hormone regulates IL-6 expression during inflammation. Journal of Clinical Investigation 108 1159-1166. (doi:10.1172/ jci12869)

Vitoratos N, Mastorakos G, Kountouris A, Papadias K \& Creatsas G 2007 Positive association of serum interleukin-1 $\beta$ and CRH levels in women with pre-term labor. Journal of Endocrinological Investigation 30 35-40. (doi:10.1007/bf03347393)

Voltolini C, Battersby S, Novembri R, Torricelli M, Severi FM, Petraglia F \& Norman JE 2015 Urocortin 2 role in placental and myometrial inflammatory mechanisms at parturition. Endocrinology 156 670-679. (doi:10.1210/en.2014-1432)

Wang Y, Tao L, Mitchell E, Bravery C, Berlingieri P, Armstrong P, Vaughan R, Underwood J \& Lehner T 1999 Allo-immunization elicits CD8+ T cell-derived chemokines, HIV suppressor factors and resistance to HIV infection in women. Nature Medicine 5 1004-1009. (doi:10.1038/12440)

Welsh T, Hirst J, Palliser H \& Zakar T 2014 Progesterone receptor expression declines in the guinea pig uterus during functional progesterone withdrawal and in response to prostaglandins. PloS ONE 9 e105253. (doi:10.1371/journal.pone.0105253)

Winterhager E \& Kidder GM 2015 Gap junction connexins in female reproductive organs: implications for women's reproductive health. Human Reproduction Update 21 340-352. (doi:10.1093/humupd/ dmv007)

Wissink S 1996 Negative interaction between the RelA(p65) Subunit of NF-kappaB and the progesterone receptor. Journal of Biological Chemistry 271 6217-6224. (doi:10.1074/ jbc.271.11.6217)

Wray S 2003 Calcium signaling and uterine contractility. Journal of the Society for Gynecologic Investigation 10 252-264. (doi:10.1016/s10715576(03)00089-3)

Xu C, Long A, Fang X, Wood SL, Slater DM, Ni X \& Olson D.M 2013 Effects of PGF $2 \alpha$ on the expression of uterine activation proteins in pregnant human myometrial cells from upper and lower segment. Journal of Clinical Endocrinology \& Metabolism 98 2975-2983. (doi:10.1210/jc.2012-2829)

Yoneda S, Shiozaki A, Ito M, Yoneda N, Inada K, Yonezawa R, Kigawa M \& Saito S 2015 Accurate prediction of the stage of histological chorioamnionitis before delivery by amniotic fluid IL-8 level. American Journal of Reproductive Immunology 73 568-576. (doi:10.1111/aji.12360)

You X, Liu J, Xu C, Liu W, Zhu X, Li Y, Sun Q, Gu H \& Ni X 2014 Corticotropin-releasing hormone (CRH) promotes inflammation in human pregnant myometrium: the evidence of CRH initiating parturition? Journal of Clinical Endocrinology \& Metabolism 99 E199-E208. (doi:10.1210/ jc. 2013-3366)

Young A 2002 immunolocalization of proinflammatory cytokines in myometrium, cervix, and fetal membranes during human parturition at term. Biology of Reproduction 66 445-449. (doi:10.1095/ biolreprod66.2.445)

Yuan M, Jordan F, McInnes I, Harnett M \& Norman J 2009 Leukocytes are primed in peripheral blood for activation during term and preterm labour. Molecular Human Reproduction 15 713-24. (doi:10.1093/ molehr/gap054)

Received in final form 2 September 2016

Accepted 19 September 2016

Accepted Preprint published online 19 September 2016
() 2016 Society for Endocrinology Printed in Great Britain 